\title{
THE BIRDS OF
}

BRECONSHIRE

E. CAMBRIDGE PHILLIPS 


\section{Smithsonian Institution Sibraries}

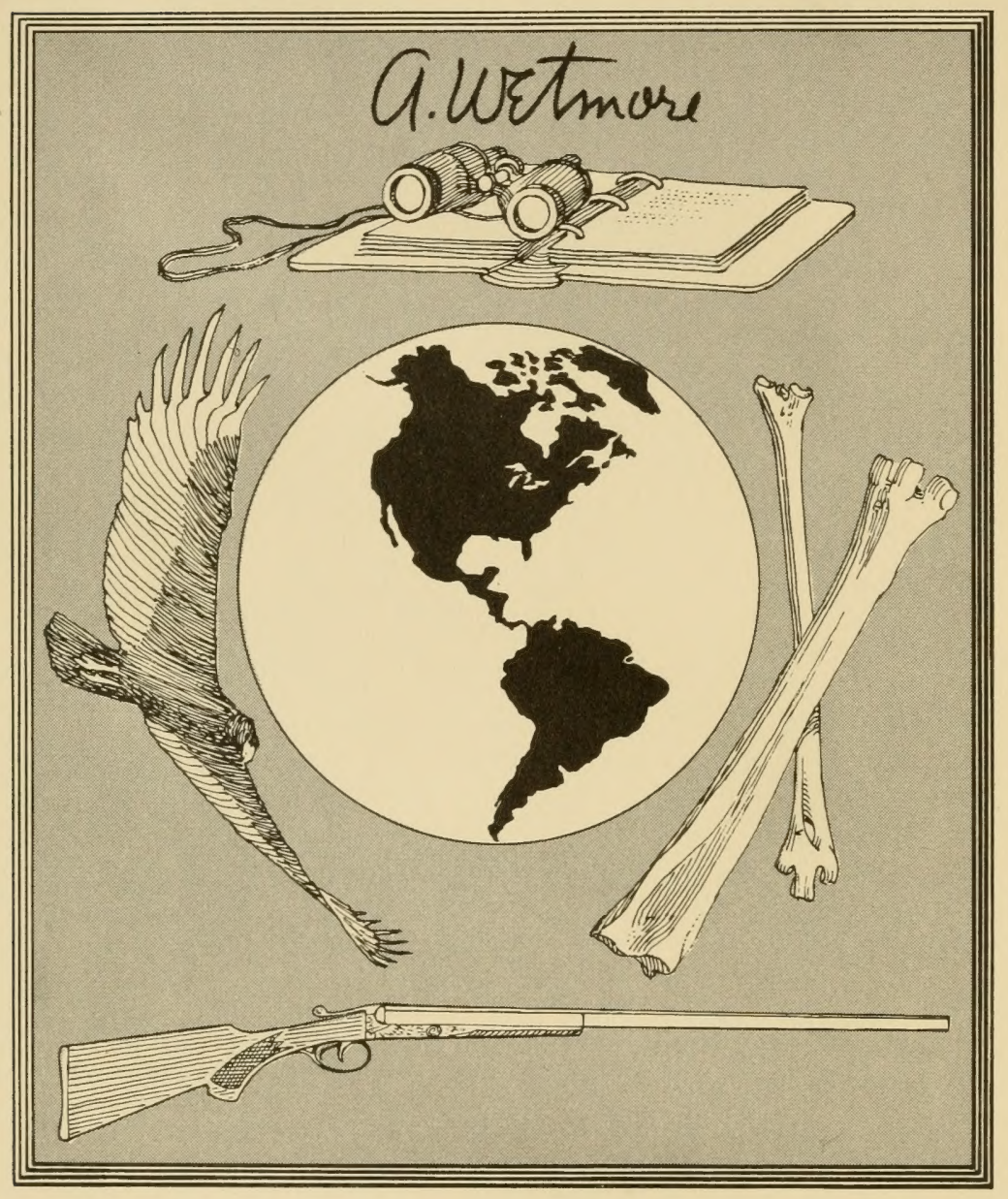

Alexander Wetmore

1946 SixthSecretary 1953

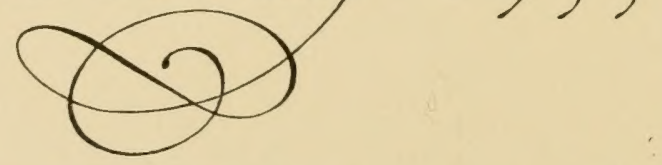




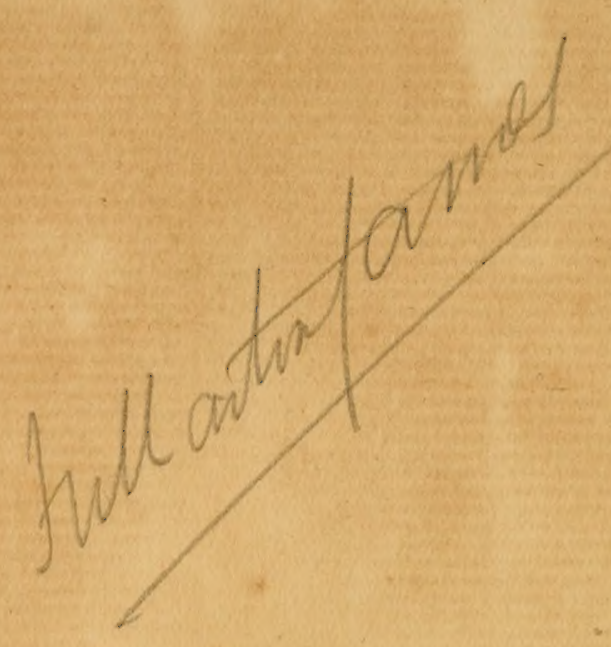





\section{THE}

\section{BIRDS OF BRECONSHIRE,}





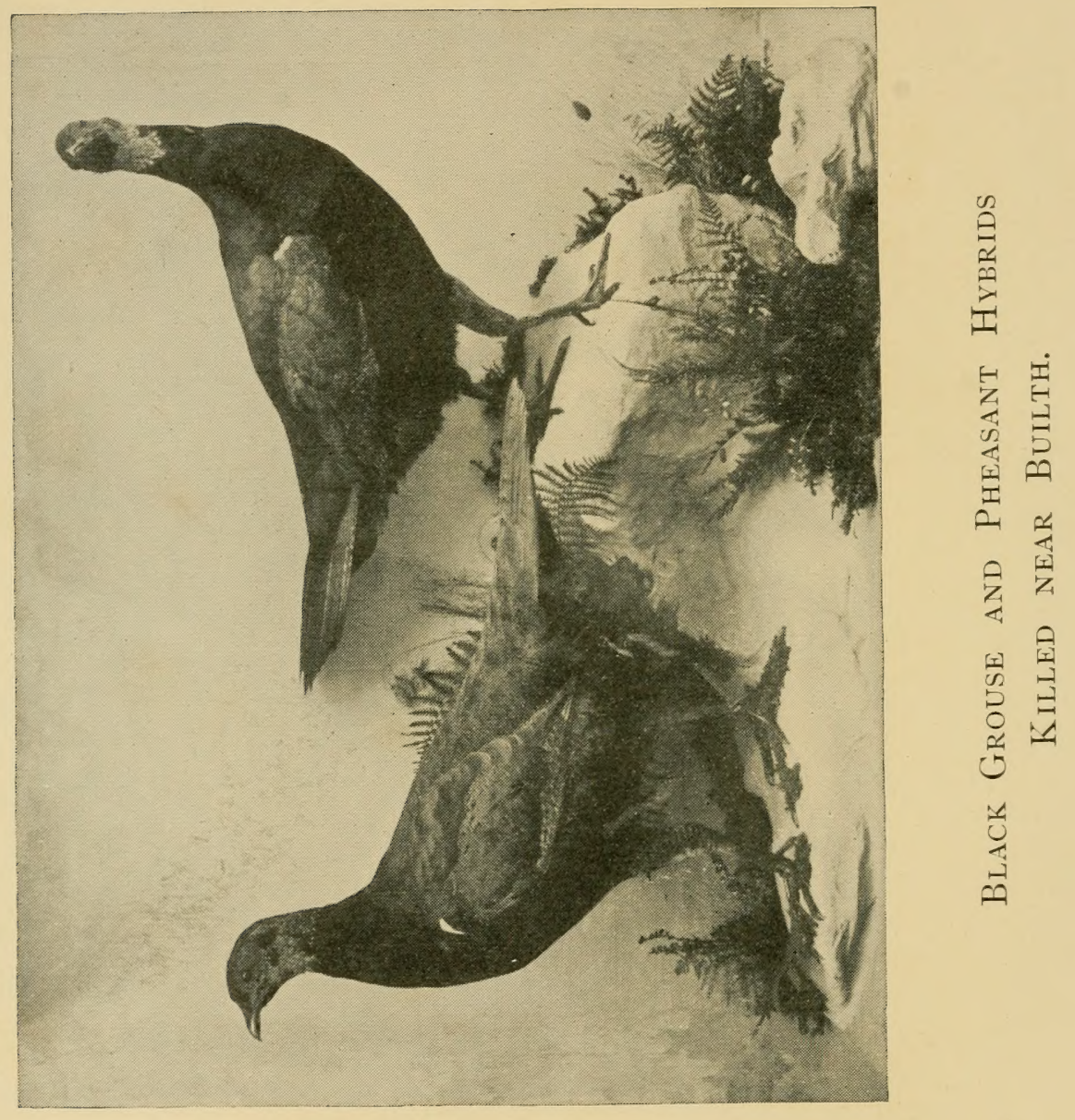




\section{THE}

\section{BIRDS OF BRECONSHIRE}

BY

E. CAMBRIDGE PHILLIPS,

Fellow of the Linnean Society of London;

Member of the Britush Ornithologist's Union;

Member of the Permanent International

Ornithological Committee;

Hon. Member of the Woolhope Naturalist's Field Club, \&c., \&ैc.

Where birds like watchful clocks the noiseless date And intercourse of times divide.

Henry Vaughan, "Biluriat," 1650.

WITH TWO ILLUSTRATIONS.

BRECON :

Printeid and PUblished by EDwin Davies.

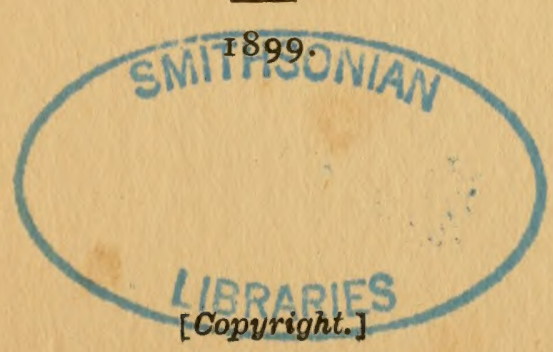



TO MY FRIEND AND BROTHER-NATURALIST,

\section{ALFRED THOMPSON CRAWSHAY,}

IN SOME ACKNOWLEDGMENT

OF MUCH VALUABLE INFORMATION

OBTAINED FROM HIM,

AND IN MEMORY OP MANY PLEASANT DAYS

TOGEYHER WITH ROD AND GUN,

I DEDICATE THIS BOOK 



\section{PREFACE TO FORMER ISSUE.}

Having for many years been in the habit of jotting down the occurrence of the rarer British birds in this county, as the reports have reached me from time to time, and as no list of the birds of this county has hitherto been published, I determined, at the suggestion of a few friends, to bring out the same in a series of papers, which have appeared accordingly in 'The Zoologist.'

Owing to the favourable reception accorded to the above by some of our leading ornithologists, I have thought it desirable to reprint the 
viii. PREFACE TO FORMER ISSUE.

same in book-form for private circulation.

It has been suggested that the birds of this county do not differ from those of other counties; but the various books and lists of the birds of nearly all the counties of England and Wales that have been published prove the contrary. Many birds that once were common are now but seldom seen, and if seen are usually shot, and so generally perish, I regret to say, unobserved and unrecorded; for instance, the Kite, Milvus regalis, still nests in a few secluded parts of this county, yet in England, in most counties, it is extinct, and probably will be so here in the course of a few years. That careful observer of Nature, the late Mr. John Lloyd, of Dinas, Brecon, in one of his interesting poems, alluding to the gradual 
PREFACE TO FORMER ISSUE. iX.

decrease of this and other birds,

says :-

"Well I remember, in my boyish hours, Gazing with rapture on the fan-tail'd Kite, As, hovering full o'er Brecknock's ivied towers, Slowly he wheeled his solitary flight.

Now 'mid the landscape he is seen no more, Fanning his broad wings in the noontide sun, Scared from his circuit on that'customed shore, By prowling keeper arm'd with trap and gun.

Hence with each year more dull our woods become, The tapping Woodpecker, the chattering Pie, Now rarely heard: the whocping Owl is dumb, The Raven calls not to his mate on high."

The above verses were written more than thirty-five years ago, and assuredly our birds, with some few exceptions, have not increased since then. The Crane (Grus cinerea), Bustard (Otis tarda), and Peregrine (Falco peregrinus) are extinct, and but for the care of a few landowners, the Black Grouse (Tetrao tetrix) would long ere this have followed their example. I therefore hope, before our list gets smaller, that this little work may be of 
X. PREFACE TO FORMER ISSUE.

some future value as a trustworthy record of the birds that have occurred in this county up to the date of publication, and as such I venture to present it to my readers.

Although my list may not be quite complete, as no doubt reports of the occurrencc of a few birds, which have not yet found their way into it, will reach me; yet I think I may say that the following pages are the result of accurate observation and carefully sifted information.

I must also take this opportunity of tendering my sincere thanks to all those who have so kindly assisted me with information, especially Mr. J. Dilwyn Llewellyn, of Penllergare, Swansea; Mr. Alfred Crawshay, of Llansaintfread, Brecon; Miss Lloyd, of 
PREFACE TO FORMER ISSUE. Xi.

Llandefailog, Brecon; and, last but not least, Mr. John Williams Vaughan, jun., of The Skreen, Erwood.

I must also thank Mr. Harting, the Editor of 'The Zoologist,' for various hints and suggestions.

The rough sketch of the Kite's nest, (then) forming the frontispiece, was made by me soon after visiting the spot with Mr. J. Dilwyn Llewellyn.

Before concluding, let me ask those of my readers who are aware of the occurrence of British Birds in our county or its borders, other than those described in my list, to kindly communicate the same to me, with, if possible,-and this is all important, - the time of year 
Xii. PREFACE TO FORMER ISSUE.

and date, and any attendant circumstance that may have come to their knowledge.

E. C. P.

Brecon, August, 1882. 


\section{ERRATA ET CORRIGENDA.}

\section{Page Line}

$x, 8$, for occurencc read occurrence.

24, 22, for gym read $Y$ sgrech goch.

43, 4, for of read for.

43, 5, for Philomelda read Philomela.

50, 9, for Yarellii read Yarrelli.

5I, I9, for those read these.

62 , 8, for Losia read Loxia.

67 , I, for colour read colours.

68, I8, for Eurapœus read Europœus.

74, 7, for all of read of all.

IoO, 3, for brest read breast.

IO7, 29, for has read had.

II2, I3, for flying read fly.

I16, 9, for allowing read nearly allowing.

I34, 2I, for was picked read was one picked. 


\section{TRANSLATION OF WELSH.}

\section{Page 27.}

"The colour of the Ouzel being (like) large calves."

$$
\text { T. Aled. }
$$

"The song to the black oxen."

"So goodly as the Ouzel art thou."

T.A.

"Not one will contend with the note of the Ouzel."

Dafydd Alaw. I500.

Page 136.

"The Crow made her nest on high And the Gall on her bed" (i.e., the ground).

Sion Dafydd. I460. 


\section{P R EFACE.}

From the foregoing it will be seen that it is now nearly I 7 years ago that I printed for private circulation a List of the Birds of this County. Since then I am glad to say lovers of Birds here have greatly increased, and the study of ornithology has spread among all classes. Many birds have also occurred which have not before been recorded, whilst some have increased, notably the Peregrine, Black Grouse, Stock-Dove, Nuthatch, and the Greater and Lesser Spotted Woodpeckers; and others have to a certain extent decreased. Still the list has now reached a 
most encouraging total, and, as I have carefully noted the occurrence of every fresh bird up to the present time, and there unfortunately being (what is so much required) no Natural History Museum in the County, I have yielded to the solicitations of many of my friends and resolved to publish the list in its entirety, trusting that it may be useful to all bird lovers, and possibly be of some value here and elsewhere at a future day.

I have re-written and considerably enlarged a great portion of $\mathrm{my}$ first issue and have in all cases where possible added the Welsh name to each bird and in this I have had much assistance from a rare old Welsh Dictionary by Edward Williams (Bardd Glas Morganwg), the Blue Bard of Glamorganshire, printed in Brecon in 1826 . It was 
evidently compiled by a man who possessed some knowledge of Birds, as will be seen by my Welsh Notes on the Eagles, Owls, and Crows, most of which I have taken from it. It is, however, much to be regretted that many of the Welsh names applied to various species of birds at the present day are generic and not specific. The deep Welsh known to cultured Welshmen is rarely used in everyday life, and scarcely ever written, hence many of the old Welsh names of birds have died out, and in their stead names of general application have come into vogue, such as are in common use in South Wales at the present day, and the names I have obtained from Williams's Dictionary, and the quotations with the dates which he gives from his favourite Bards, some of which I have reproduced, 
xviii.

PREFACE.

to a certain extent, confirm this.

Whenever I have omitted the Welsh name of any bird I have been unable to obtain it for the reasons above stated.

Being a poor Welshman myself, I desire to express my gratitude to the Rev. J. B. Jones, of Brecon, the well known Welsh scholar, for his attentive kindness in revising the Welsh names.

I have also gratefully to acknowledge the varied valuable and useful information that I have received from all parts of the county and elsewhere from time to time, without which it would have been utterly impossible for me to have completed my list, and especially are my thanks due to Miss Lewis Lloyd, Miss G. E. F. Morgan, 
Miss Charlotte Thomas, Lord Glanusk, Sir John Dilwyn Llewelyn, Bart., Professor Newton, Col. Wood, Capt. Hotchkis, Capt. Sandeman, Capt. Swainson, The Rev. John Bowen, Messrs. Alfred Crawshay, Herbert Crawshay, J. H. Gurney, Alfred Gwynne-Vaughan, David Gwynne-Vaughan, J. E. Harting, C. Venables-Llewelyn, Digby S. W. Nicholl, Howard Saunders, $H$. Edgar Thomas, J. WilliamsVaughan, Rees Williams, Vaughan Powell, and those of my sons who have aided me in my efforts.

I desire to thank $\mathrm{Mr}$ David Price, of Brecon, for the facilities he has afforded me in allowing the Black Game and Pheasant hybrids killed by his late fatherin-law, Mr. Price, of Builth, and now in his possession, to be photographed, as they form a most in- 
teresting frontispiece to this Book.

I wish to add my acknowledgments to the "Woolhope Naturalist's Field Club" and also to the "Zoologist" for much instructive material obtained from their notes and papers.

There are also others who have given me many interesting items whose names I cannot recall at present, but who, I hope, will forgive me if I have not mentioned them, and be content with the sincere assurance that their information has helped to finish what I hope may be deemed a trustworthy and accurate list of the Birds of this County.

Let me conclude by adding an extract from a poem on "The Bird," most assuredly written of a Breconshire bird, in I650, at 
Newton, within half a mile of this house, by the Breconshire poet, Henry Vaughan, the "Silurist," a kinsman of my wife's, which poem may possibly be new to many of my readers.

\section{E.C.P.}

The Rock, Brolch, Breconshire, May, I899. 



\section{THE BIRD.}

Hither thou com'st: the busy wind all night

Blew through thy lodging, where thy own warm wing

Thy pillow was. Many a sullen storm,

For which coarse man seems much the fitter born,

Rain'd on thy bed

And harmless head.

And now as fresh and cheerful as the light

Thy little heart in early hymns doth sing

Unto that providence, Whose unseen arm

Curb'd them, and cloth'd thee well and warm.

All things that be praise Him; and had

Their lesson taught them when first made.

HENRY VAUGHAN,

Silurist, 1650. 



\title{
THE
}

\section{BIRDS OF BRECONSHIRE}

BY

\section{E. CAMBRIDGE PHILLIPS,}

\author{
F.L.S., \&C.
}

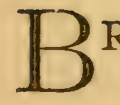

RECONSHIRE is not a large county, and is so well known that it needs but a slight description. It embraces among its general features, in a marked degree, mountain and moor, valley and hill; it has one large lake, Llangorse, with numerous mountain tarns, and is drained by the Usk and partly by the Wye and their tributaries. Yet with all these advantages of Nature the Ornithology of the county is not so varied 
as might be supposed. Our grand old Beacons are, to a great extent, destitute of bird life; on the other hand, the moors, which extend over a great part of the county are fairly well stocked. On them, as of yore, the Red Grouse and Blackcock, the Wild Duck, Teal, Snipe, Curlew, and Plover still breed, though in diminished numbers. Llangorse Lake unfortunately is so constantly shot over that what should be a "home for waterbirds" now shelters only a few Ducks, Coots, Grebes, and Rails. Our rivers are, without exception, fast flowing, and water birds, unless pressed by hard weather, avoid if possible (with the exception of the Water Ouzel or Dipper) these kind of streams. The absence also of a sea-coast still further reduces the number. Notwithstanding these drawbacks, Breconshire, as the following notes will show, can boast of a fair average list of birds. Most of the rarer species are getting rarer still; in these days of cheap guns any but the most ordinary bird is at once shot down, and it is this continued diminution that has determined me to compile the following notes, which in nearly every instance have been the 
result of actual and careful observation. I purpose taking first the land and then the water-birds.

\section{GOLDEN EAGLE, Aquila chrysaëtus.}

Although there are numerous localities that are exactly suitable to its habits, I can only record one instance in which the Golden Eagle has been met with in Breconshire. About forty years ago one was killed at Penpont, near Brecon, by a keeper of the late Mr. Penry Williams, the owner, and through his kindness I was permitted to inspect the bird. It was stuffed very fairly by a private of the 23rd Regiment, then stationed at Brecon, but had not been cased. It showed no marks of captivity when I saw it, none of its feathers being worn as if from confinement. I should consider it, from its plumage, to be a bird of three or four years old, and to have strayed to the Beacons, in search of food. About this time I hear that another, probably its mate, was killed in the adjoining county of Glamorgan.

The Welsh for Eagle is Eryr; in Cornish and Breton, Er. Williams 
recognises three kinds viz., Eryr auraidd, the Golden Eagle; Eryr $d u$, the Black Eagle; and Eryr gynffon wyn, the White-tailed Eagle. He adds that many Eagles were to be seen in Wales in his generation (1826). One was killed in I776 (he does not specify the species, but probably a Golden Eagle), which he saw himself in a place called Llansanwr, near Cowbridge, Glamorganshire. It was shot in the act of killing a lamb, but its wing being only broken, it nearly killed a dog before it was despatched.

There is a place in North Wales, he says (which, however, he does not specify) called "The Eagles' Rocks," where these birds used to breed, and were still to be seen in I826. I have lately heard there is a farm house in Cardiganshire called "Crug-yr-eryr."

The Eagle, however, was never very common in South Wales, as may be surmised from the above remarks; and this is borne out by the fact that, so far as I know, we have no rock or crag that bears its name in South Wales; although we have "The Beaver's Cave" on the Towy, and "The Wolf's Leap" on the Irvon, indicating that in bygone days 
both these animals inhabited this country.

Since writing the above I have received a letter from that excellent ornithologist, the Rev. Murray A. Mathew, who formerly resided in Pembrokeshire, in which he says that one of the highest points of the Precelly Mountains is known by the name of "Foel" or "Moel Eryr"-the "Eagle's Peak" or "Tump," but the only Eagle he has heard of in Pembrokeshire of late years was one seen by a Mr. Hugh Owen in the winter of $185 \mathrm{I}$, in the neighbourhood of Haverfordwest, which frequented the covers of Picton and Slebech for some time and escaped being shot. This was probably a young White-tailed Eagle, as one is in Lord Cawdor's collection at Stackpole Court which was shot about that time. Immature examples of the White-tailed Eagle (Haliaëtus Albicilla) are observed from time to time on the Sea-bound Counties of England and Wales in autumn and winter when the young birds reared in the North of Europe are migrating towards the South; adu1ts, however, are of very rare occurrence (Saunders): I mention this to show that the bird in question was not bred in Wales. 
6 THE BIRDS OF BRECONSHIRE.

OSPREY, Pandion haliaëtus.

Formerly frequented Llangorse Lake, one being seen there in I884, and another in $\mathrm{I} 886$ by Mr. A. Crawshay. Another was killed on the Wye near Clyro, and is at present at Clyro Court. Another was for some months in the same locality, where it was seen to be fishing in the Wye, and although every effort was made to prevent its being molested, it ultimately, I believe, shared the usual fate of every rare or uncommon bird in this country, as the last I heard of it was that it was seen flying as if wounded. The Welsh is Eryr y mor.

\section{BUZZARD, Buteo vulgaris.}

Still fairly common. Many a time have I watched them soaring around, for hours together, high over the trees of Venny Wood, near Brecon, uttering their wailing, weird cry. They are still to be seen on the rocky hills adjoinging Llanwrtyd Wells and in the various wild gorges of the Beacons. Unfortunately they are easy birds to trap, and the day will come when, as in the case of the Kite, we shall, I fear, only see a few in 
the course of the year. The Buzzard has always been considered a lazy bird; when roused it is quite the reverse, and two I trapped some years ago were so defiantly grand in their attitude, that not being much hurt, I sent them to the Zoological Gardens, knowing that they would get every attention there. One of them, I believe, lived some little time. This bird is very fond of sitting on a rock, and if by chance there is one in or near any cover it may be generally trapped on it. It is very regular in its search for food, and may be seen nearly every day in the same place about the same time. A few years since Mr Edgar Thomas, of Brecon, reared two Buzzards, recently taken from the nest. They grew into splendid birds, one being singularly light in colour; he presented them to the Zoological Society of London.

I hear there is an Inn near St. David's, Pembrokeshire, nearer Cardigan and Newcastle Emlyn, with the sign "Boncath Inn " i.e., "Buzzard's Inn," and at the present time I am pleased to know that there are still a good many Buzzards in North Pembrokeshire. There is also a 
Farm House, Nant y Boncath, 6 miles on the road from Carmarthen to Lampeter.

The Buzzard in Welsh is called Boda, plural Bodaod, and this name is in general use in Breconshire, and in Carmarthenshire; sometimes, though rarely, the word Brencath is used, but this is applied to any large bird, such as

Buzzard or even Bittern.

\section{HONEY BUZZARD, Pernis apivorus.}

One was shot at Ffrwdgrech, near Brecon. I saw it in its case, but the estate having changed hands I am unable to record any of the circumstances attending its capture. It can only be regarded as a very rare visitor.

Another was killed at Danypark, near Crickhowell, by the late Mrs. Crawshay's keeper, either in $187 \mathrm{I}$ or 1872 . I am indebted to $\mathrm{Mr}$. A. Crawshay for this information. It may be mentioned that in the year I896, a pair were killed by a gamekeeper near Hereford, and were stuffed by Mr. Ashdown, who informed me the female had eggs in her. It seems a pity they were not allowed to breed in peace. 



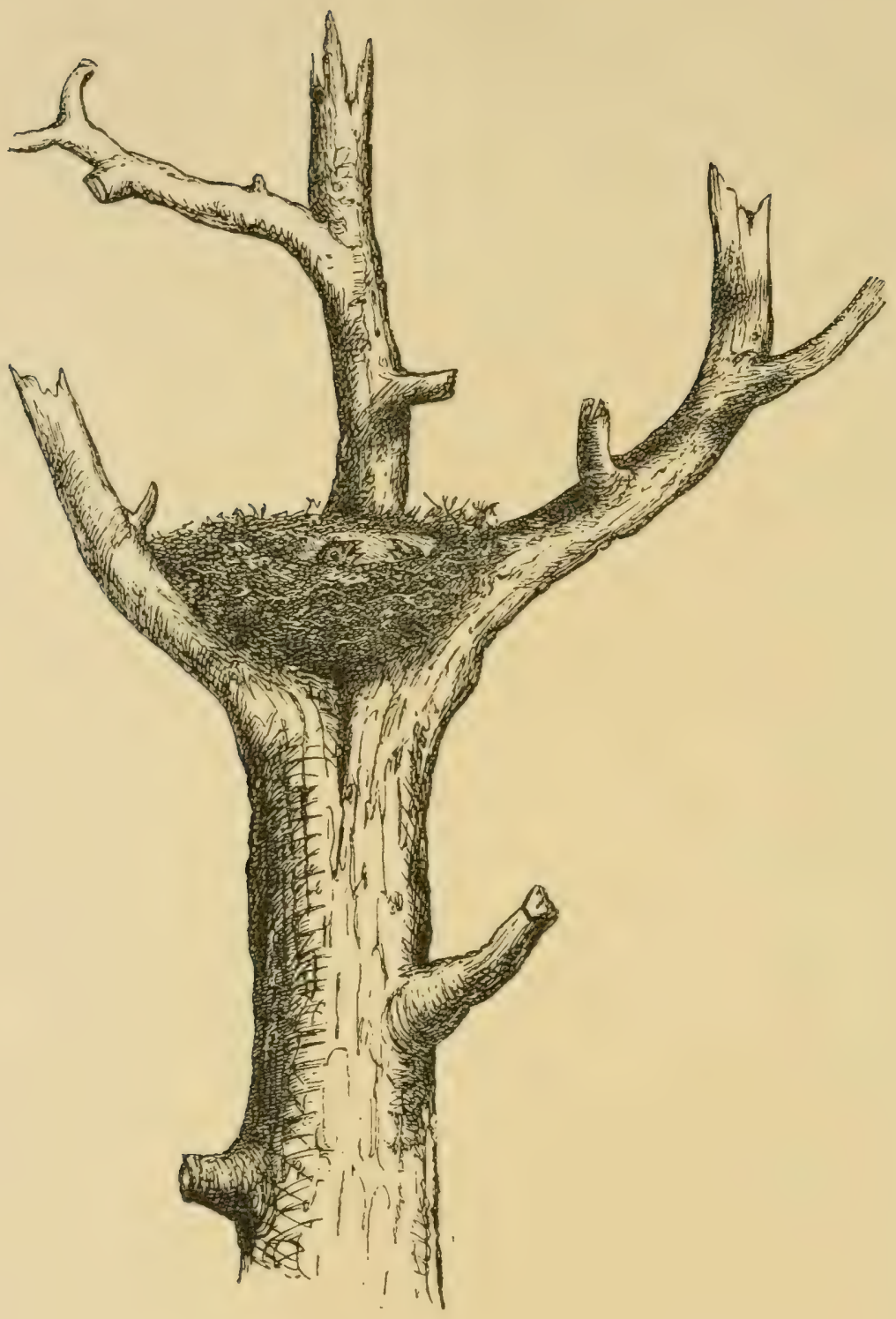

KITE'S NEST NEAR UPPER CHAPEL. 
KITE, Milvus regalis.

This fine bird is still with us. In the year 1875 it was nearly extinct, and up to that period I only saw two. Now, however, I know of places where it breeds, and occasionally one may be seen passing over at a great height. In the month of May, I875, I went with Sir John Dilwyn Llewellyn, to a place near Upper Chapel to see the nest of a Kite, and a drawing of it which I made at the time appeared, with a short description, in "Land and Water" shortly afterwards After driving as near the place as the carriage would go, we got out and walked, crossing a small valley until we reached a larch wood growing on the side of a very steep hill. The trees were large and high, and in the middle of the wood far up on one of the largest trees that suddenly forked into three gnarled branches was the nest comfortably and securely fixed between them. On striking the tree the hen bird flew out, seemingly much alarmed, whilst the male soared about in the distance, no doubt anxiously waiting our departure. By climbing up the brow of the wood we could look down into the nest, in which were three 
young ones covered with yellow down, the head of one being distinctly visible. This was in the second week of May. At the foot of the tree were some partridge-feathers, but none of those castings that are found when the young get older. The tenant told us that he had seen a quantity of castings with feathers and fur in previous years, and that in that year there were three Kites in the pairing time, but that one had left; this was most probably a young bird of the previous year that had been bred there. I hear that the Kite still frequents the same locality; but the fact of the one bird staying with the old ones so long will, I think, be sufficient evidence of their general scarcity at that time.

Up to the year I889, the Kite had increased considerably and might have been often seen soaring above the town. In that spring, however, many were killed, three or four close to the town. After that a determined effort was made by several landowners in the county to preserve the few pairs that were left, and the Zoological Society of London passed 
a special vote of thanks to them as well as myself for our efforts in that direction.

In the present year (1899), they perhaps, hardly hold their own, but as for obvious reasons it would be most unwise to mention their breeding places, I will content myself by saying that a few pairs still breed, and are protected, as far as possible, in our county.

The Welsh name for the Kite is Barcud, pronounced Barkit, and sometimes in Carmarthenshire, Barcutan, plural Barcutanod. No other name seems to be in use for this bird, although a friend of mine, a native of Pembrokeshire, tells me that when a boy he well remembers a clever old keeper applying it to the Buzzard. Welsh boys at the present day, when flying their kites, call them "barcutan papyr" (i.e., paper kites).

In the Welsh Bible the word Kite is rendered Barcud (Levit. xi., I4, Job xxviii., 7). In the dictionary alluded to, Williams gives it as Barcud, Barcit, Barcitan, Barcut, Barcutan; English, a Kite; Cornish, Bargez; Bretagne or Breton, which is nearly the same as the 
Welsh, Barquet. The word Barcud seems more generally used than Barcutan; and from the terminal cud, pronounced kit, comes our word Kite. Since some of these notes were first jotted down, I have had the pleasure of reading Mr. Harting' most interesting article on the Berkute or Bargut of Eastern Turkestan, which appeared in the "Field." In this he states that the name for the Eagle, which is trained for hawking by the Kirghis and Bashkyris, is variously spelled Berkute or Bearcoote; in Russia, Berkute. In Eastern Turkey it is Birgut and Bargut, whilst in Persia it is Bargut and Bargud. The similarity to the Welsh Barcud or Barcit is certainly very remarkable; and it is probably very ancient Welsh, which has been handed down from the earliest times, when possibly this name was generally applied to all large birds of prey in the then semi-civilised world. From the above it would appear that the term is fairly general in Asia, and unknown in Europe, except where introduced into Russia and Turkey, until Brittany is reached; then to be known in Cornwall; and finally, in all its purity, in Wales. 
GREENLAND FALCON, Falco candicans.

A beautiful specimen of this lovely Falcon was trapped at Buckland, by Mr. Gwynne Holford's keeper, Smith, in the winter of 1893. It was in perfect plumage, and was given away by him to a publican at Brecon, as a "light Buzzard." He sent it to the late Mr. Cording, of Cardiff, who carefully mounted it, and it was then secured by Mr. A. Crawshay for his collection. Another was afterwards killed in the neighbourhood of Brecon, and is at present preserved in the town. Whether they were a pair or not I am unable to say. In Welsh, "Falcon" and "Hawk" are different forms of the same word; Brynhebog, being a farm house in Llandilofawr, and Brynhawc, a farm house in Llanwenog, Cardiganshire.

PEREGRINE FALCON, Falco peregrinus.

I think increasing slightly. I have known of several specimens killed some years ago, but it never bred here. I am enabled to state this as a fact, from the information I received from old Morgan the falconer, a small farmer living at 
Nantyrodyn, near Llanwrtyd Wells, who I may designate as one of the last of his race. I made his acquaintance when fox-hunting near the cave of Twm Shon Catti, on the Towy, some thirty years ago; and even now I can see the spare wiry figure, with long white hair waving about his shoulders, his eyes fairly flashing with excitement as he sprang from rock to rock and cheered the hounds. Many a chat have I had with him about his favourite sport, falconry. He told me that for many years he used to walk from Llanwrtyd, in Breconshire, to Snowdon and back nearly every year to obtain young Falcons, as he could not procure any in Breconshire. He trained and flew them himself, but when I knew him he was too old to climb for them. He was very fond of a Merlin, and had trained the female Sparrowhawk to fly at Landrails. As he lived in the wildest part of the county, no one interfered with him; he was a true lover of nature, and had a wonderful knowledge of everthing appertaining to the habits of birds. Poor old Morgn! kindly in his nature, pleasant in his manner, though wild at times as the hawks he trained 
and as the scenery among which he lived -he is gone; and with him in this part of the county at least, the practice of his favourite pastime. I have seen several stuffed specimens, notably a young Falcon obtained from the rocks at Abergwesyn.

Mr. A. Crawshay has killed it near here, and I saw a pair some three years ago flying over the Crug near Brecon. It is also to be seen now from time to time on the Allt, Llansaintfraed.

In Welsh the Peregrine Falcon, or Hunting Falcon is Febog; a Falconer is Hebogydd, i.e., one who hunts with Hawks. Sometimes Gwalch is given for Hawk, and Gwalchur, a Hawker, i.e., a man accustomed to catch birds with a Hawk Hebog, (Williams). The words Hebog and Gwalch and Falco are probably synonymous. The Imperial Dictionary, however, gives the word Gwalch as Welsh for Falcon, and adds that it means literally "a crested one." If this is so then it is possible that this word applies to the Hooded Falcon, the hood that is used in Falconry having a crest or tassel at the top. Williams 
states that Falconry was very general amongst the gentry of Wales before the introduction of shot-guns.

In Merionethshire, the late Lord Lilford informed me that the Peregrine at the present day is called Cudyll glas na Craig, but this is no specific name, and simply means "the blue Hawk of the rock"; he adds that the Merlin is there called Cudyll glas Vach, i.e., "The little blue Hawk." This word Cudyll is the same as the word Ciryll, commonly used for all small Hawks in this neighbourhood, and hereafter alluded to.

\section{HOBBY, Falco subbuteo.}

Very rare in this county. I have seen two stuffed specimens, one a large hen bird which was killed near Brecon, and another killed near Nantgwyllt.

A third was trapped on the Allt near this house by Mr. Gwynne Holford's keeper on the $4^{\text {th }}$ September last year, who brought it to me for identification. I have had it preserved; it was an adult female bird. It is, of course, only a summer visitant, but it very possibly bred here. 
MARSH HARRIER, Circus ceruginosus.

I fear extinct. This bird was formerly common on the hills between the Storey Arms and Merthyr. There were three beautiful specimens killed in this county, and splendidly preserved by Leadbeater, in the possession of the late Mr. David Thomas, of Brecon.

\section{HEN HARRIER, Circus cyaneus.}

Now nearly extinct. A pair for years nested on the Breconshire side of the river Wye near Nantgwyllt, Radnorshire, but were at last trapped on account of their extreme destructiveness, and their nest and eggs taken. I am indebted for the above information to a lady, one of the Nantgwyllt family, herself a keen lover of Nature and a great preserver of all wild birds, who kindly showed me the hen bird which had been preserved and was in her possession. She has also a specimen each of the Hobby (above alluded to) and Merlin, killed at the same place, and several Buzzards, which bears out my statement that the Buzzard is still far from rare in the county. In Welsh Hebog llwydlas. 
MERLIN, Falco cesalon.

Cannot be considered common. I have only seen it once on the wing near Brecon. A friend of mine killed one near the town in excellent plumage, and I have seen several others stuffed. This beautiful and bold little fellow should be let alone; there are plenty of small birds for him, and if he does occasionally fly at higher game by all means let him have it. Sir John Dilwyn Llewellyn thinks that this hawk is often taken on the wing for the male Sparrowhawk, and that it is more common than is generally supposed, and his authority is not to be slighted. A Merlin's nest with 4 eggs was taken on the Grouse Hill, at Wauntinka, in the heather in June, I888.

KESTREL, Falco tinnunculus.

Very common.

The English name of Windhover seems most appropriate to this common bird, for it is always hovering in the air. Many writers assert it is a useful bird, from the quantity of mice it destroys; and no doubt this is so. I think, how- 
ever, that it kills what it can. A friend of mine had a nice brood of Pheasants, which he put under a hen, and for greater security he put them directly in front of his window; day by day they improved in size, but decreased in numbers, until they were nearly all gone, in spite of careful watching; one day, however, like a flash of light a hawk darted round the corner and took one of them; a lucky shot laid him low, and on picking him up the culprit was found to be a Kestrel. He had taken them all.

SPARROWHAWK, Accipiter nisus.

Very common. I once found a Sparrowhawk in a singular situation; going to my garden in Brecon one night in the dead of winter, to catch some game bantams that roosted in a thick holly tree, I turned a lantern on them suddenly, and there saw a hen Sparrowhawk roosting close by the bantams! I carefully put my hand over her back, but directly I touched her she dashed off into the darkness and I saw her no more; what she was doing there I cannot make out, but I imagine that the night being bitterly cold she must have 
crept up to the fowls for warmth. On another occasion during a continued snow I saw a Sparrowhawk make a most determined attack on a duck-wing bantam cock, and had she not been driven off I believe she would have killed him. A station-master who lives on the borders of this county, and who keeps canaries in the large glass window of the station, tells me that he has caught three Sparrowhawks that have struck at the canaries, two of which dashed right through the glass and were killed, and the other stunned itself and was picked up outside the window.

Sparrow Hawk is Ciryll, plural Ciryllod, and this name is commonly used in Breconshire, but $I$ am sure it is also applied to the Kestrel. Williams renders Sparrow Hawk, Gwipai, Gwipia, and Gribiar; and adds, "A kind of Falcon (Walch, i.e., Gwalch), or Hawk (Hebog) of a small kind," evidently meaning by this that it was used for hawking; most probably he has mistaken the Sparrow Hawk for the Merlin. I know the word Ciryll is generally used by the farmers for any small Hawi. Williams also gives Llemysten but this, I imagine, is very 
ancient Welsh.

LONG-EARED OWL, Otus vulgaris.

I consider very rare here. Sir John Dilwyn Llewellyn has observed it in Glamorganshire, and I have known of so very few specimens, that I imagine it favours Glamorganshire more than this county.

One was killed at Buckland in August of last year by Smith, the keeper, and preserved. Another was killed on the I3th November, I89I, at Cilhowey, Lower Chapel, on Col. Morgan's Estate and was seen by me in the flesh on the following day. It is now preserved in Brecon.

SHORT-EARED OWL, Otus brachyotus.

Also very uncommon. Although I have for years shot over open heaths and the like places, I have never seen it. It is fairly common in Glamorganshire. I have, however, had it reported to me.

\section{BROWN OWL, Syrnium aluco.}

Very common throughout the county. In nearly all the woods about Brecon, and in the Priory groves adjoining the 
town, as evening approaches one may hear them. They used to frequent a large elm-tree growing close to my house in Brecon, where they terrified the servants, who were most superstitious, with their cries. Among the Welsh it is considered most unlucky to kill an Owl, but whether this accounts for their numbers is more than I can say; it may possibly have something to do with it.

A Grey variety of the Brown Ow1, a remarkably fine bird, was killed at Ffrwdgrech, near Brecon, in I889, and is in the collection of Capt. Swainson of Brecon. I saw another close to the Crug, near Brecon, in I89I.

There are two phases of this bird now recognized, a red and a grey, the latter occurring most in the Southern Counties of England. (Aflalo).

WHITE OR BARN OWL, Strix flammea.

Now very uncommon throughout the county. When returning from an evening's ramble I used sometimes to see it gliding with noiseless flight over the fields. On all "keepers' trees," where one so often picks up a lesson in 
Ornithology, the Brown Owl outnumbers the Barn Owl considerably. The keepers, as a rule, wage dire war against the poor Owls; they make a great show on a tree, and are very easily trapped; while, after all, the harm they do is small. The Barn Owl is a positive benefactor to the farmer from the quantities of mice it kills.

All Owls at the present day are spoken of in Welsh as Dylluan only, plural Dylluanod sometimes Dallhuan: from Dall, blind, and Huan, sun, i.e., "Sunblind." Williams, however, gives Dylluan, Tylluan; Irish, Ean; Hebrew, Helil; and he especially mentions five kinds, viz., Dylluan wen, the White Owl; Dylluan frech, the Speckled or Streaked Owl, probably the Long and Short-eared Owls; Dylluan rudd the Brown or Ruddy-coloured Owl, which he also styles the "corpse bird," probably from its frequenting churchyards; Dylluan gorniog the Horned Owl, which, as he afterwards says, is nearly as large as the Eagle-he probably means the Eagle Owl; and he finally mentions "a small Owl, which is the smallest of Owls," and which can be 
no other than the Little Owl.

\section{GREAT GREY SHRIKE, Lanius excubitor.}

I imagine this to be only a very occasional winter visitor.

One was seen at Tredustan, near Tregunter, in I88I, by the late Col. Roche and his brother. It was easily recognized by them as they had often observed it on the Continent. Another was seen at Tregunter on the $4^{\text {th }}$ January, I89I, by Major E. Roche and Mr. Ed. Thomas. Another has been observed by Miss Lloyd, of Llandefaelog, and another was killed at Saint John's Mount, near Brecon, some years since.

RED-BACK SHRIKE, Lanius collurio.

Common. I have often observed it in the hay-fields adjoining the town perching on the hedges, the brilliant colour on the back of the cock rendering it very conspicuous. Welsh, gym.

MISSEI, THRUSH, Turdus viscivoms.

Very common; it nested in my garden at Brecon every year, where it attacked 
every living thing in the shape of a bird, uttering its harsh grating cry. It is one of our boldest birds in the breeding season, and seem during this time to lose every vestige of its shyness. Welsh, Fronfraith s'yn byw.

SONG THRUSH, Turdus musicus.

Very common. I think there are greater quantities of Thrushes this spring than I ever remember before. Welsh, $Y$ fron fraith.

\section{BLACKBIRD, Turdus merula.}

Very common. They seem to stand the cold better than the Thrush. I have observed several more or less white, and of all the Thrush family this bird seems peculiarly susceptible to white markings in its plumage.

In the year 1893 an undoubted Blackbird's nest, which contained a bright entirely blue egg was brought to me, which I sent to Mr. Howard Saunders, who says in his excellent Manual of British Birds, that it is well known that the Blackbird and Song Thrush occasionally interbreed, and that these blue eggs 
may be the result of the union. Personally $I$ am an utter unbeliever in wild bred hybrids, except when one of the parent birds is unable to obtain a mate of its own species, which could not be the case in the union of a Blackbird and a Thrush. The nearest approach I have seen to this union was in May, 1897, when I saw near Llangunider a Cock Blackbird feeding a Thrush, presumably a hen, on a hedge by the side of the road. As against this I have had brought to me a bright blue egg of the common Peewit, where any chance of hybridism is utterly out of the question. The Welsh for Blackbird is Aderyn du.

FIELDFARE, Turdus pilaris.

Common in winter, when its appearance is hailed with delight by the sportsman, who knows that it arrives about the same time as the Woodcock. It is a very wary bird, and can take excellent care of itself, as anyone who has attempted to shoot it, has no doubt found out to his cost. Welsh, Sorcas llwydd. 
REDWING, Turdus iliacus.

Equally plentiful; it arrives at the same time and generally in company with the Fieldfare; it sometimes stays late on in the spring, and once in Wiltshire I heard it singing at that time. Until then I had no idea its song was so beautiful. A flock of several were singing on a thorn, and, not knowing the song, I killed one and found to my surprise it was a Redwing. Welsh, Coch yr aden.

RING OUZEL, Turdus torquatus.

Fairly common at times on our heathery moors. I have observed it on a hill called the Crug, near Brecon, and generally in the autumn. It nests regularly on the Eppynt Hills in this County.

The Welsh is Merwys. Williams seems to have known this bird very well and gives three quotations from his favourite Bards, viz. :

"Lliw'r merwys yn lloi mawrion."

T. Aled i Ychen duon.

"Mor fad a'r merwys ydwyd." T.A.

"Nid un ymryson don merwysod." Dafydd Alaw, I500. 


\section{WATER OUZEL, OR DIPPER,}

\section{Cinclus aquaticus.}

One of our commonest birds. Wherever the stream flows swiftest and strongest, there on a rock in mid-stream -the happiest and merriest little fellow of all our birds-you will see the Dipper. Such an active, bustling, and important bird; now dabbling in the water, now splashing about in his glee, then off down stream like an arrow, uttering its gladsome cry. This bird is a great favourite of mine, and I have often watched it carefully. The late Frank Buckland used to say he was not sure whether it ate the salmon-spawn or not It may, but I think it feeds principally on water-insects. I have never observed it with spawn in its mouth; and if perchance it should take fish for its first course, I am sure we can spare the spawn. I am informed by those that have had the cruelty to try it, that if you rob the Dipper's nest it will not forsake it, but lay an incredible number of eggs: such is its fearlessness. Some years ago, the late Col. Morgan, of Bolgoed, told me that passing over a 
small bridge near his house, under which was a Dipper's nest, he noticed that the storm of the previous night had blown the nest very much about, and also that the opening was much exposed to the storm. Going to look at it the following day, he found the nest repaired, but the opening was put the other side, in order to shelter it from the wind. In this case the Dipper seems to have shown a considerable degree of intelligence. The Welsh is Fron fraith fach $y$ dwfr, or rhegen $y$ drefr.

GOLDEN ORIOLE, Oriolus Galbula.

Five of these beautiful summer visitants have been reported to me-and all cocks. It is most likey that there were hens with them, but the more sober plumage of the females would have prevented them from being so easily seen. One was seen at the end of March or the beginning of April, I891, at Maesderwen, about three miles from Brecon, two others both near Talgarth in the month of May, I89I, and another close to this house last summer. The minute manner in which these three last were described 
to me left no possible doubt of their occurrence. It will be noticed that three birds were seen in I89I. It is probable, therefore, they visited us that year in some numbers like the Crossbill in I887-8. Another, a cock, was killed in the orchard at Porthamel, near Talgarth, in the early part of June this year, and sent to London for identification. It is singular that this bird should have been killed close to where the others were noticed at Talgarth in I89I.

\section{SPOTTED FLYCATCHER,}

Muscicapa grisola.

Common. It may be generally seen in some of the gardens around Brecon, where it hawks for flies, and its movements when so doing are very elegant and beautiful. The Welsh is Clerdalizer llywiog.

\section{PIED FLYCATCHER, Muscicapa atricapilla.}

This county seems to be a favourite resort of this bird, and I may say with truththat it is fairly plentiful. It bred in my garden at Vennyfach, also in 
Brecon, and it nests also in several places in and near the town. Ornithologists residing in this county agree with me that it is far from rare: and therefore I can only arrive at the pleasant conclusion that, although elsewhere generally considered a scarce bird, this county seems exceptionally favoured. It was unusually plentiful here in 1897 . The Welsh is Clerdd aliwr brithog.

\section{RAVEN, Corvus corax.}

Still common, and I think will remain so, a great part of the county being unpreserved, and these birds frequent the mountains and highest hills, which are very little disturbed. Wherever you happen to come across a dead sheep you are sure to hear the hoarse croak of the Raven. This bird lives to a great age. When a boy, in Wiltshire, I used to pay a visit-generally on a Sunday-to some friends that lived in an old manor house where there was a tame Raven; he was then about twenty years old, and full of all sorts of mischief and iniquity, but being a great favourite and a good talker he had pretty much his own way. I 
remember him well, for on one occasion he took a small slice out of my leg, ut mos fuit, and retired to the top of a spout to digest it, amidst my yells and the threats of the whole party. Happening to be near the place twenty-five years afterwards, I ventured to ask for my old friend, and to my surprise out he came with the same sidelong hop, the same malicious twinkle in his eye, and looking more sleek and diabolical than ever. His death occurred shortly afterwards for taking a similar liberty with a large dog that he did with my leg, as he got a nip in return that killed him. He must have been fifty years old when he died, and was one of the finest birds I have ever seen. The Raven is a bird of ill omen amongst the Welsh, and for that reason is seldom, if ever, kept as a pet by them.

It is worth remarking that at the present day the word Bran is applied indifferently both to the Rook and the Crow, but not to the Raven, which is still, and always has been, Cigfran, or Meat Crow. Williams, however, adds, Ydfran, a Rook, or rather Seed or Corn 
Crow; Cogfran, a Jackdaw, or Cuckoo Crow, probably from its smaller size; and Milfran, a Carrion Crow, literally Animal (eating) Crow; and Morfran, a Cormorant or Sea Crow.

\section{CROW, Corvus corone.}

One of the commonest birds in the county, and one we can well do without. I believe this bird does more mischief than any hawk; he is always about the same place, and is always on the look out, not for carrion, but for something better; a small leveret, a partridge's nest of eggs, or a half-grown rabbit-it all comes the same to him; whilst a weakly lamb has its eyes out before he well knows where he is. Although they generally work in twos and threes they come home to roost together, in numbers of from twenty to thirty, to the same roosting-place, and by waiting them in a few may be killed; but by far the best way to kill them is to trap them with an egg and a common gin.

In the year I884, a White Carrion Crow was killed at Aberyskir, near Brecon, by Mr. Rees Williams. It was 
a bird of the year. The late Mr. Marshall, of Belmont, Taunton, was anxious to obtain it for his collection of Albinos, but he was unable to do so. At the sale of Mr. Williams' stuffed birds, it however realised by auction, $£ 4$ ros.-an Albino Crow being a great rarity.

Very singularly Mr. Rees Williams killed another quite White Carrion Crow, about three months afterwards, in a field near Coedmawr, Brecon. This would be about three or four miles from where he killed the first, but he does not think it was the same hatch, as he often saw the former bird by itself before killing it. Unfortunately the feathers of the latter bird were in such a bad condition that it was impossible to have it preserved.

\section{ROYSTON OR HOODED CROW,}

\section{Corvus cornix.}

I have never yet seen this bird alive in the county, and can only record with certainty four instances of its having been met with here. One by Mr. Williams Vaughan, another in November, 1895, when Captain Sandeman saw a 
Hooded Crow fly across the river at Danypark, Crickhowell ; another killed on the Allt, on the Buckland estate, by Cross, Mr Gwynne Holford's keeper, and a fourth, which was killed on Lord Glanusk's estate near Crickhowell, and is at present in his possession. It is rare with us, but though it occurs occasionally in Glamorganshire, it is evidently only an accidental visitant. The question of wild-bred hybrids again crops up here, and the curious results of birds bred between the Common Crow and this bird and their offspring in every graduated stage of colour, may be seen in the beautiful case of these hybrids brought from Siberia by the late Mr. Seebohm, now in the entrance of the Natural History Museum in the Cromwell Road. Many naturalists, however, Professor Newton among the number, do not admit their specific distinctness.

\section{ROOK, Corvus frugilegus.}

Plentiful, there being several large rookeries in the county. I once visited a rookery near the borders of Breconshire, composed of oak and other trees with a very large ash growing in the centre, 
36 THE BIRDS OF BRECONSHIRE.

and the owner informed me that, although he had lived there many years, he had never seen the Rooks build in that tree. Sometimes, indeed, a pair of young ones would begin to build a nest there, but it was instantly torn to pieces by the older birds, with every symptom of disapprobation. Why they should avoid this particular tree, which was quite sound, he could not say, but their continued and determined rejection of it showed a unity of counsel and fixity of purpose which to me was inexplicable. Only once during my residence here have I seen a pied or parti-coloured Rook, and that was a bird with whitish wings. Mr Crawshay, however, killed two Rooks with white on their wings, in the Rock Wood close to his house at Llansaintfraed.

CHOUGH, Pyrrhocorax graculus.

Although it occurs sparingly amongst the rocky cliffs of the Glamorganshire coast, I am unable to include it amongst the birds of this county.

JACKDAW, Corvus monedula. Very common indeed, particularly 
about the tower of the grand old Priory Church of Brecon. Sometime since I saw a curious specimen of a white Jackdaw; the plumage of this bird was not only pure white, but its legs, claws, and eyes were white. I think among the Crow family an albino is very rarely seen. Mr. Butler, of Llangoed Castle, killed there some years ago, a curiously buff coloured Jackdaw.

\section{JAY, Garrulus glandarius.}

Very common in all our woods; in the hard weather of I880 the poor Jays were put to great straits and came into the town gardens for food. One was caught feeding with my poultry in one of the aviaries, where it must have pushed itself between the wires to get to the food. For a shy bird like the Jay this was somewhat singular. The barred blue feathers on the wing are much sought after for a particular Salmon Fly. Welsh, Ysgrech y coed.

\section{MAGPIE, Pica caudata.}

Very common, and, like the Raven, considered to be a bird of ill omen. 
Indeed I know of no bird that is more generally noticed in this respect, and the old adage,- "One, sorrow; two, mirth; three, a wedding; four, a birth,"-seems implicitly believed in by many of the country people. The Welsh for Magpie is Pioden.

NUTCRACKER, Nucifraga caryocatactes.

I have seen but one stuffed specimen in Wales, and that was a bird in perfect plumage, which was killed many years since in the adjoining county of Glamorgan.

\section{STARLING, Sturnus vulgaris.}

Although this bird breeds here pretty plentifully, yet the number that roost in the reed-beds of Llangorse Lake during the autumn must come from other parts. If you are on the lake about four o'clock in the afternoon you will see flock after flock flying over and pitching in the reeds, and this continues until they are all come; then with a roar-and no other word expresses it-the whole flock rises in one living mass, sweeping over 
the Lake close to the reeds in a black moving cloud; then threatening to settle again, then up and round once more, with a regularity and precision of movement that is beautiful and wonderful to witness, until at length, their drill being over, they finally settle and roost for the night. Their numbers on these occasions must be in thousands, and during the time they are settled they keep up a continual chattering, but are silent whilst on the wing.

In 1896 I saw in a field on Tal y Bryn Farm, Buckland, a Starling in a flock of others, beautifully and regularly spangled all over with white. I did not disturb it, but regret to say I did not afterwards see it. Major Jones-Williams killed about three years ago a buff coloured Starling in Cui Park and has had it preserved. Considering the enormous numbers there are of this bird, I consider it remarkably free from variation in colour. The only other instance I ever saw was at Burytown, near Highworth, Wiltshire, where amongst an immense flock I saw a pure white bird. Williams give the Welsh for Starling as 
40 THE BIRDS OF BRECONSHIRE.

Drudwen, and quotes "Morlo pen yw'r drudwenod" (Starlings) Howel Dafydd, I46o.

\section{ROSE-COLOURED PASTOR, Pastor roseus.}

I have the pleasure of recording the occurrence of one of these beautiful birds, if not actually in the county, at least close to the borders. It was shot in an apple tree at Cynghordy (one of the ancient seats of the Gwynnes), not far from Llanwrtyd, and was fortunately preserved. It was an adult male, in good plumage, and when alive must have been a splendid bird. It had been stufted some years when I examined it, and the delicate rose-colour had somewhat faded.

HEDGESPARROW, Accentor modularis.

Pretty plentiful with us, but not nearly so much so as in England. Williams calls it Gwichell y gog, but I expect he alludes to the Wryneck. Others, Brych $y$ cae.

ROBIN, Erythaca rubecula. Common. The country people here 
THE BIRDS OF BRECONSHIRE. $4 \mathrm{~T}$

say that the year-old bird kills the twoyear-old bird, but I think the weaker generally goes to the wall. One day a man called my attention to two Robins fighting, and one killed the other in an incredibly short space of time; he then picked up and showed me the dead bird, and it certainly was a fine old male, in beautiful plumage. It appeared to have been choked by the victor, as its plumage was almost unruffled. Capt. Sandeman found a nest of pure white Robins eggs this year at Courtygollen, near Crickhowell. The Welsh for Robin is Bronrhuddyn, Red Breast. (Williams).

REDSTART, Ruticilla phonicura.

Is invariably called here "firebrandtail," and is very common in the gardens around Brecon and in the woods of the county. The Welsh is Llostrhuddyn, Red Tail.

BLACK REDSTART, Ruticilla tithys.

One seen some years since resting for a short time on the roof of Llanthomas, a house situate near Hay, in this county. As far as can be remembered, it was in 
42 THE BIRDS OF BRECONSHIRE.

the month of November. I am indebted to Miss Charlotte A. Thomas, of Llanthomas, herself a great bird observer, for this information.

WHEATEAR, Saxicola cenanthe.

Common on all our hills and moors, but in no great numbers. Welsh, Aderyn y grenith.

STONECHAT, Saxicola mubicola.

Not very common in the county. Welsh, Tinwyn y garn.

FURZECHAT, S. mubtra.

Common, their being still a great quantity of furze on the lower part of most of our hills. They affect favourite localities, for whilst in some places covered with furze they may be constantly observed, on other hills equally well covered they are hardly ever to be seen. Welsh, Tinwyn cwynfanllyd.

SEDGE WARBLER,

Salicaria phragmitis, and

REED WARBLER, S. Strepera.

Both fairly common, particularly the 
latter in the neighbourhood of and around Llangorse Lake, where there is an abundant growth of reeds. The Welsh of Sedge Warbler is Hesg ganwr.

\section{NIGHTINGAIE, Philomelda Luscinia.}

Sparingly scattered over the county. There is a common saying here that the Nightingale is never heard westward of the Bwlch, which is distant about eight miles from Brecon, on the Crickhowell side of the county; and although I have heard it near Brecon, ten miles on this side of the place referred to, I am disposed to believe that there is a great deal of truth in the saying.

A few years since a Nightingale nested near the Rectory garden, Talgarth, where its song attracted crowds of people. This was a very beautiful songster, and people came from far and near to hear it. I saw the bird later myself, but did not hear its song, as probably it had young. It did not appear the following year, but another did some years after. I must not omit to add that it is very common in the adjoining county of 
Hereford. The Welsh for Nightingale is Eos.

BLACKCAP, Sylvia atricapilla.

Fairly common. It used to breed in my garden at Vennyvach, near Brecon, every year. The Welsh is $Y$ Penloyn.

GARDEN WARBLER, Sylvia hortensis.

Uncommon, but I think increasing. I have known of its nest and eggs being taken on several occasions. A pair nested behind Captain Swainson's house, Brecon, in June, I89I. Welsh, Canwr yr ardd.

GRASSHOPPER WARBLER, Salicaria locustella

Rather rare but increasing. I have heard it many times in the still summer evenings. A nest and five eggs were taken by Captain Swainson at Vennyfach, 29th May, 1896, and sent to Mr. Harting for identification. I believe they are now in the Natural History Museum. $\mathrm{He}$ has also taken the eggs on other occasions. 
THE BIRDS OF BRECONSHIRE.

WHITETHROAT, Sylvia cinerea.

Very common here. Welsh, $Y$ greddfwyn cyffredin.

\section{LESSER WHITETHROAT,}

\section{Sylvia sylviella.}

Rare; I have seen it on several occasions. My youngest son took a nest of this bird, containing eggs, at Tynycae, near Brecon. Others have noticed it from time to time. Like many of our migratory birds (notably the Spotted Crake), it probably visits various places in the county year after year, whilst others are constantly avoided.

WOOD WREN, Phylloscopus sibilatrix.

The rarest of these three warblers. Welsh, Canzer y coed.

WILLOW WREN, Phylloscopus trochilus.

Fairly common. Welsh, Brychydd yr helyg.

CHIFF CHAFF, Phylloscopus rufa.

I do not consider it to be quite so 
common as the Willow Wren. It is spoken of in Carmarthenshire as $Y$ Chiff Chaff but the Rev. J. B. Jones tells me this is not pure Welsh.

The above three Warblers visit this county yearly but sometimes in greater number than others, so that the above remarks would apply to an average year. It must not be forgotten, however, that the difference between the Chiff Chaff and Willow Wren is so slight that it is almost impossible to distinguish the one from the other unless you have the birds in your hand.

\section{GOLDEN-CRESTED WREN, Regulus cristatus.}

Very common, the numerous plantations in the county being most suitable to its habits. It is usually considered a scarce bird, probably from its small size and inconspicuous colour, but I see it constantly, and there can be no doubt of its abundance here.

This is a very hardy bird, and during the severe frost of I880, when so many other birds perished, these merry little 
fellows were actively searching for their food in the firs and larches as usual, not seeming to care or feel the bitter cold. Welsh, Diyw melyn gribog.

\section{FIRE-CRESTED WREN, Regulus ignicapillus.}

On the 27th February, 1899, hearing a Crested Wren in my garden with a somewhat different note from the ordinary Gold-crest, my son shot it with a catapult for the purpose of identification, and $I$ found it to be an undoubted Firecrested Wren. The stripe through the eye, the sort of black moustache from the corners of the mouth, and the black stripe under the crest, with the white between, left no doubt of the bird's identity. I have always thought this bird occurred occasionally with us, and on that account included it in my list of birds of the county, but it was and is much rarer than I at first supposed. I omitted to say that the above bird was a cock, with all his colours of the very brightest, also that when he flew he darted out from the tree and back, something after the manner of the White- 
throat; he also appeared slightly larger than the Gold-crest. He had another with him, which we secured a few days after, very near the same place where we secured the cock. This was the hen bird, and she was much smaller than the cock, and less bright in all her markings, but they both had the beautiful gold sort of mantle on the sides of the neck. I dare say I shall be blamed for killing this pair of birds, but I have been looking out for the Fire-crest for the last eighteen years and this is the first time I have been able to positively identify it in the flesh as occurring here, as from the incessant movements of both this bird and the Gold-crest one is unable to distinguish the stripes on the head which almost alone marks the difference in the two birds. I have had them both preserved.

COMMON WREN, Troglodytes parvulus.

Very abundant, and like the Robin, a universal favourite with the Welsh. The Welsh for Wren is Dryw (Williams).

GREAT TITMOUSE, Parus major.

Very abundant. A lady formerly 
living in Brecon had continually suspended from her verandah a hard piece of fat bacon. Many birds came to feed on it; amongst others a great number of Tits, who seemed to consider it their special property. Welsh, Yswidw Mawr.

\section{BLUE TITMOUSE, Parns ccruleus.}

Equally common with the last named, and one of the boldest and most attractive little birds we have. Welsh, Yswidw Glas

COLE TITMOUSE, Parus ater.

Fairly common, as also is the closely allied MARSH TIT, palustris. I have often observed them both, and several specimens of each have been brought to me from time to time for identification. The Welsh for Cole Tit is Yswidw $d u$.

\section{LONG-TAILED TITMOUSE,}

Parus caudatus.

Plentiful. It sometimes leaves the woods and comes to our gardens for a very brief visit, always in small flocks, and always with the same eager and 
impatient movements, the same quick and restless flight, and uttering all the while its somewhat weak and plaintive note. Although the plumage of the bird is very loose, it seems to bear the cold here as well as the rest of the Tit family. Welsh, Yswidw hir ei gwt.

Of the British species of Wagtails, viz., the PIED WAGTaIL, Motacilla Yarrellii, the GREY WAGTAIL, $M$. sulphurea, and the YeLLOW WAGTAIL, $M$. Rayi, all are very common here. The Usk being a good trout river, whenever there is a rise of the fly on, the Wagtails may be seen in numbers actively running along its banks, flying and hovering in the most graceful way over the water, and constantly seizing a fly, whilst the splash of the heavy trout, as they, too, take their share, complete one of the most pleasing pictures of nature. In Welsh the Pied Wagtail is Tinsigl y groys brith; the Grey Wagtail Tinsigl y groys llwyd; and the Yellow Wagtail Tinsigl $y$ gwys melyn.

\section{BLUE-HEADED WAGTAIL, Motacilla Alava.}

Capt. Sandeman writes me that he 
THE BIRDS OF BRECONSHIRE. 5 I

found, what he was certain, after days of watching with a stalking glass, was a Blue-headed Wagtail's nest. He says he might have shot the bird, but, having satisfied himself of its identity, he didn't care to. I have, myself, no doubt that I saw one last spring, on the slates close by my smoke-room window, and as there was only a yard between us, I had an excellent opportunity of observing it carefully. It was an old male in splendid plumage, and it stopped some time before it flew away. I never saw it afterwards.

\section{MEADOW PIPIT, Anthus pratensis.}

Now abundant in the county. Welsh, Pibganwer $y$ ddol.

TREE PIPIT, Anthus arboreus.

Now common. Both those last named birds have increased of late years in a marvellous way. The Welsh for Tree Pipit is Pibganwr $y$ coed.

\section{SKY LARK, Alauda arvensis.}

Common. Occasionally a small flock 
is observed passing over, but one never sees anything like the large flocks that occur constantly on the Wiltshire and other Downs. I think we are too high and wet for them, and it must not be forgotten that, comparatively speaking, there is very little land under tillage here. Welsh Uchedydd.

WOODLARK Alauda arborea.

Very uncommon. I have only seen it twice since I have resided here. Capt. Swainson has also obtained it, and it occurs sparingly near Talybont. Welsh, Uchedydd $y$ coed.

WAXWING, Ampelis garmulus.

I can only record one instance of the occurrence of this bird, and that was killed near Llanwrtyd.

TREE CREEPER, Certhia familiaris.

Generally scattered throughout the county. I often used to see it actively creeping up some fine old elms in my garden at Brecon. Welsh, Ymlusgydd $y$ coed. 
NUTHATCH, Sitta casia.

This bird has been certainly increasing for the last few years. It was formerly scarce here. I have seen it several times in my garden, when $I$ was attracted by its piping note. Miss Lloyd, of Llandefaelog near Brecon, who so kindly gave me the particulars of the nesting of the Hen Harrier at Nantgwyllt, tells me that the Nuthatch breeds at Llandefaelog, but she thinks the district too cold for them. I see it, however, much more often than formerly.

SNOW BUNTING, Emberiza nivalis.

Some were reported me as having been seen near Llanthomas, Hay, in the month of January, 1879.

COMMON BUNTING, Emberiza miliaria.

Uncommon throughout the county. I get them occasionally reported; it is much more plentiful in the adjoining county of Cardigan, especially near the Sea Coast. Welsh, Aderyn bras yr $y d$.

REED BUNTING, Emberiza schariclus. Common, especially in the neigh- 
54 THE BIRDS OF BRECONSHIRE.

bourhuod of Llangorse Lake, and on the banks of the Canal. Welsh, Aderyn bras yr $y d$ mewn corsydd. Williams gives it as "Ysgidogon," and he is probably correct.

YELLOW BUNTING, Emberiza citrinella.

Very common. The late Mr. Marsh, Rector of Sutton Benger, near Chippenham-whose lectures on British Birds are always remembered with pleasure by those that had the privilege, as I often had, of hearing them-used to say that the Yellow Bunting, if properly roasted between two vine leaves, was equal to, and not easily to be distinguished from, the celebrated Ortolan, E. hortulana, so eagerly sought after by gourmets on the Continent. Welsh, Aderyn melyn bras yr $y d$ or melyn yr eithin.

CIRL, BUNTING, Emberiza Cirlus.

I have had the great pleasure of being the discoverer of this little Bunting in this county, if not in South Wales. It was unknown here until I saw my son, J. Vaughan Phillips, kill one with a catapult outside my garden at Brecon, 
near the top of King street, on the 15th March, I888. It was a cock bird in beautiful plumage, and $I$ have it stuffed at the present time. In 1890 Capt. Swainson took the nest in a field behind the Memorial College, Brecon, and he has killed several birds for the purpose of identification. It has also occurred in several other places in the county. No doubt it has always existed here, but from its resemblance to the Yellow Bunting it was unobserved before.

CHAFFINCH, Fringilla calebs.

May with truth be said to be the commonest bird we have, and the boldest. A curious variety of a uniform delicate fawn-colour, which I have had the pleasure of inspecting, was killed at Velinnewydd by Mr. Williams-Vaughan of that place.

Some years since, my second son noticed a Chaffinch fluttering on a beech tree near Brecon. He caught it, and, upon examination, found that it had one of its legs firmly wedged in the husk of one of the beech 
nuts, and was kept a prisoner with its head downwards. It had seemingly been in this strange position for some time, as the bird was a perfect skeleton, and would, no doubt, have soon died from exhaustion. It was not until the heat of the room had opened the husk that the foot came out. The Chaffinch in Welsh is Winc or Gwinc (Williams) whence probably the English name "Twink."

BRAMBLING, Fringilla montifringilla.

Not common, but it sometimes occurs here in flocks in the winter. When shooting at Merthyr Cynog in January, I896, I saw a large flock of Finches, and not being certain of their identity, I killed several at a shot when I found, much to my surprise, they were Bramblings.

GOLDFINCH, Fringilla carduelis.

Very general all over the county. We are fortunately not very much troubled with professional birdcatchers, with their call-birds and nets, but only by a few amateurs, so that I think this may in 
some way account for their numbers. I often see them both in large and small flocks, and a pair or so nested in my garden in Brecon nearly every year. Welsh, Gwas y Sierri (Williams) or peneuryn.

SISKIN, Fringilla spinus.

This bird I see occasionally during the winter, and generally moving in small flocks.

LINNET, Linota cannabina.

Common enough, but I think not so much so, or in such large flocks, as in England. In Welsh, Llinos, from whence probably the name.

TWITE, Linota flavirostris.

Fairly distributed in the winter throughout the county.

MEALY REDPOLI, Linota linaria.

I am not able to say with certainty that we have this bird with us. I have not observed it; still it is so very liable to be confounded with the common 
58 THE BIRDS OF BRECONSHIRE.

Linnet that it is very probable it occurs occasionally. The bird catchers, of which there are a few in Brecon, tell me, however, that they take it from time to time.

\section{LESSER REDPOLI, Linota mescens.}

Not common, but still occurring in fair numbers. A station-master on one of our principal Welsh lines tells me that he catches both the Redpolls, especially the Lesser Redpoll, in his traps when taking Goldfinches, and that he can sell the latter, but not the former. I imagine however, that the Linnet is mistaken by him for the Mealy Redpoll. The Lesser Redpoll makes a lively little pet, but its rich marking soon vanishes in confinement. Welsh, Llinos bengoch, the Redheaded Linnet.

TREE SPARROW, Passer montanus.

Resident with us, but in no great numbers. I have seen it killed at Upper House, Tredomen, and elsewhere, and a pied one was killed near Brecon by one of my sons. Welsh, Aderyn y to geir mewn bargod. 
THE BIRDS OF BRECONSHIRE. 59

HOUSE SPARROW, Passer domesticus.

Very common, very noisy, and very impudent, as everywhere else. I think also increasing during the past few years.

In 1897, one of my boys killed a beautifully pied Sparrow at Talybont. I may also add that a pure white Sparrow was killed at Burytown in Wiltshire, and is now in the Natural History Museum, but the Sparrow is very liable to albinism. Williams gives the Welsh as Golfan or Aderyn $y$ tô, a bird of the thatch.

GREENFINCH, Coccothraustes chloris.

Common throughout the county. Welsh, Llinos werdd (Williams).

HAWFINCH, Coccothraustes vulgaris.

Now increasing. The late Mr. Roche, of Tregunter, told me that some thirtyfive years ago a large flock of these birds established themselves in the large trees near his house, and that they stayed there nearly the whole winter, which, if I recollect right, was a severe one. $\mathrm{He}$ well remembers catching numbers of 
60 THE BIRDS OF BRECONSHIRE.

them in traps and keeping them in cages, but he has not observed any since that time.

A young Hawfinch, just out of the nest, was picked up on the Hay road, near Brecon. It was shown to me and was afterwards kept by Mr. Wilson, seedsman, of Brecon, for some years. It grew into a very large bird, and was, I believe, unfortunately killed by a cat. It has been killed at Buckland and elsewhere in the county, and has been observed at Merthyr Cynog, also at Llandefaelog by Miss Lloyd. It breeds near Crickhowel, and, I may add, is fairly common in the adjoining county of Hereford. On April the Ist, 1899, Cross, the keeper at Buckland, sent me down a beautiful cock bird which he had obtained there. I mention this more particularly because it seems to occur more often near Buckland than anywhere else in the county.

BULLFINCH, Pyrrhula vulgaris.

Very common. I sometimes see it in the garden, but not often, for it is, I think, a wood-loving bird. Welsh, 
THE BIRDS OF BRECONSHIRE. 6I

Chwifanydd (Williams).

\section{CROSSBILI, Loxia curvirostra.}

Rare here except for occasional visitations. In the winter of, I believe, 1866, they were abundant all over the county. Some tall larch trees in my garden at Vennyfach were literally covered with them one morning. Not knowing their note I killed several, but after that I did not disturb them. One of the birds killed was a cock in splendid plumage of a bright red; another a cock of a bright yellow; whilst the rest were hens of a dull olive-green. They stayed with us for some time, but. all left about January, except one hen that stayed about the place until April, when I missed her; she frequented one larch tree in particular, and was so tame that she would take no notice of anyone's approach. I have often watched her within a few feet, and her mode of feeding on the seeds of the fir-cone, and indeed her actions generally, invariably reminded me of those of a parrot. I felt quite sorry when she left us to return no more. I think if she had had a mate 
62 THE BIRDS OF BRECONSHIRE.

she would have nested here. In the same year they were equally. plentiful in the adjoining county of Carmarthen. In the winter of $1887-8$, there were great flocks all over the county, some staying until quite late in the spring of I888.

\section{PARROT CROSSBILL, Losia pityopsittacus.}

Two killed by Capt. Swainson. A1though this bird is not considered by modern authorities as entitled to subspecific rank, yet as it is distinguished from the last named bird by its very much larger bill, I have thought it best to record it as above.

GREEN WOODPECKER, Picus viridis

Plentiful throughout the county. On the Crug, a hill near Brecon, it is common, and may often be seen on the short turf there feeding, and, if disturbed, flying with its undulating flight to the nearest tree, uttering at intervals its loud and somewhat weird cry. Welsh, Coblyn$y$-coed.

GREATER SPOTTED WOODPECKER, Picus major.

Increasing. I have seen a beautiful 
THE BIRDS OF BRECONSHIRE. 63

hen bird killed by Mr. Williams-Vaughan, at the Skreen, on the Wye, his Radnorshire residence, and close to the borders of Breconshire. The cock bird flew about in loneliness for some time, and was afterwards killed, and the pair are now in that gentleman's collection. There are also several stuffed specimens in the town that have been killed at or near Brecon.

I have also often seen it at Talybont, and it nested in the Priory Grove, near Brecon. Captain Swainson has several birds stuffed, and I killed a fine old cock bird in the autumn of 1890 , near Talyllyn, and had it preserved.

\section{LESSER SPOTTED WOODPECKER,}

\section{Picus minor.}

Commoner than Picus major, but still far from plentiful. Occasionally one pays me a visit, and $I$ have seen it in Vennyfach Wood, and other parts of the county. Its variegated plumage of black and white makes it so attractive that one cannot fail to notice it.

It also breeds regularly at Llansaintffraed near this house. 
64 THE BIRDS OF BRECONSHIRE.

THE GREAT BLACK WOODPECKER, Picus martius.

The refusal on the part of Professor Newton and of Messrs. Seebohm and Howard Saunders to give this bird a place in the list of British Birds, is now so well known that it is with the greatest hesitation and not with the slightest intention of setting up my humble opinion against theirs, that I now allude to a bird seen by myself and one of my sons as it was flying from an oak at Dinas, near Brecon, on Whit Monday, I885, and reported by me in "The Zoologist" (I885, p. 305). I certainly should not have noticed it but for its cry, which was most startling, loud, and resonant, and quite unlike anything $I$ ever heard before or since, although I have been a field naturalist for forty years. The cry was very like the cry of the Curlew when unexpectedly disturbed, but was louder and more weird-like, and I think I may add, almost human in its shrillness. I admit that this cry is most difficult to describe, but that it was a Woodpecker, and a Black one, I have no doubt. And 
THE BIRDS OF BRECONSHIRE. 65

if it was not Picus martius, what bird was it? I omitted to state that it flew with a bold sweeping flight, and with its tail slightly forked. I heard its cry twice afterwards, but saw it no more.

WRYNECK, Jynx torquilla.

Not common with us but its nest has been taken by some young friends of mine. I imagine it occurs very sparingly throughout the county, although, as a summer migrant, its numbers are of course liable to variation. The Welsh name for Wryneck is Gwas-y-gog (the servant of the Cuckoo).

\section{HOOPOE, Upupa epops.}

This beautiful bird occurs only as an accidental visitor with us. I can, however, out of many reports, give three with certainty, viz., one killed at Cathedine, near Llangorse, by the late Mr. David Brown, and late in the possession of Mr. David Thomas of this town, and since given me by Mr. Edgar Thomas of Brecon; another killed some years since at Ffrwdgrech, near Brecon; and a third killed in the neighbourhood 
of Llangorse by Mr. Penry Lloyd, who then lived at Brynderwen, and who was kind enough to give me this information. No doubt others have occurred from time to time but were unrecognised and so are unrecorded.

CUCKOO, Cuculus canorus.

Very common. In I88o one frequented my garden in Brecon where, as the gardener expressed it, it "sang lovely." The Welsh name is Gog.

KINGFISHER, Alcedo ispida.

Fairly numerous on the Usk and Wye and on the Brecon Canal, but certainly increasing during the last two or three years. It is only occasionally seen on the mountain streams, and I think that it prefers slow-running water. It is very susceptible of cold. Looking one frosty day over the Honddu Bridge, near the Castle, in Brecon, I saw close by the houses a Kingfisher perched, like a dull emerald ball, on a willow by the slack water that turns the mill. Repeated stones failed to move him, but at last he seemed to wake up, and, showing all his 
THE BIRDS OF BRECONSHIRE. 67

beantiful colour of blue and orange, he flew a few yards further on, when he pitched again, and positively refused to move, he seemed so perished with the cold; and so we left him master of the situation. May not the coldness of this climate account for their not increasing faster here, for I think they are seldom if ever molested?

I see it almost every day flying along the river under my windows and it nests annually in a steep bank near this house. The Welsh name is Glas $y$ Dorlan.

THE SWALLOW, Hirundo rustica; MARTIN H. urbica; SAND MARTIN, H. riparia; and SWIFT, Cypselus apus.

Are very common here; in fact I see no difference between their numbers here and in England. The Sand Martins occur in numbers on the banks of the Usk. My boys tell me that if you take a young Sand Martin from its hole, and place it at the mouth of another hole, it will not move; but place it at the mouth of the hole in which it has been 
hatched, and it will scuttle out of sight directly.

In the year 1887 , a beautiful nearly White Swift made its appearance on the river at Dinas, and visited us again for the succeeding two years. It was all white except its wings, a little of its tail, and a small portion of its head, and was a most striking looking bird on the wing. I did not see it in I89o. I fear it was destroyed. On the IIth, August, I890, my second son shot a White Sand Martin on the lake at Llangorse. Williams gives Swallow in Welsh, Gwenol, and adds Gaenol yr dwr, Martin, or Water Swallow; and Gwenol y glenydd, the Sand Martin.

\section{NIGHTJAR, Caprimulgus eurapceus.}

Common on all our heathy hills. Many a time have I had it brought to me as a great rarity, and as often have I totally failed in impressing on my visitor that, if he only watched "between the lights," he might see them almost any summer evening. How well I remember my first introduction to this 
THE BIRDS OF BRECONSHIRE. 69

bird. Many years since, alas! in an old country seat in Wiltshire, where I spent many happy days, I took my gun one summer evening, and, followed by old "Sahib," the retriever, I started to get a rabbit. Passing through a small park and down by the "Ladies' Well," I came to a field almost surrounded by woods. It was twilight, and all was still, save the tinkling of the distant sheep bells on the Cherhill Down, and the faint ringing of the many chimes borne from the hills of the "White Horse." No rabbits were out, so "Sahib" and I watched and waited, until an old doe cautiously appeared and began distrustfully to feed; then a little hedgehog came out, working about with his nose in the grass in a wonderful way. All at once the old rabbit stopped feeding, the hedgehog seemed inclined to roll himself up, and old "Sahib" pricked his ears, as, with a splendid swift-like rush, gliding noiselessly through the air, a bird came circling by; a minute more and I heard its curious jarring cry, and forgot everything else in watching with a delight that comes back to me even now, the 
beautiful and fairy-like flight of the Nightjar.

It is well known to naturalists in Wales, and is a beautiful bird, feeding exclusively on night insects, such as moths, beetles, cockchafers, \&c., and is, in fact, the swallow of the night. Its evolutions in its flight when it is hawking, if I may use the expression, for its food, are perfectly wonderful; turning, gliding, and circling in the most graceful manner, and in the utmost silence, except when uttering its weird, jarring cry, that, once heard, can never be forgotten. This cry is usually uttered as the bird sits lengthways on a branch, and it is said that it never sits crossways.

Nature, in her never-erring bounty, has provided the Night-jar with a very large mouth with which to take its food. Sevieral strong bristles project downwards from the edge of the mandible, forming, when the bird opens its mouth, a perfect insect trap; and, in order to clear its mouth and its bristles from the various portions of insects that may adhere to 
them, it has its middle toe furnished with a pectinated (not a serrated) claw. Anyone seeing this perfect little comblike appendage cannot, I think, fail to come to the above conclusion concerning this claw, although some naturalists have advanced other theories. I may state also that the heron (Ardea cinerea) has a serrated claw, used, no doubt, for the same purpose in removing fish scales.

The good that the Night-jar must do as an insect killer is incalculable, and, as such, it deserves the utmost protection.

I omitted to state that some have supposed that it captures its prey with its claws, but in my opinion it does so on the wing, flying along with its open trap-like mouth, with which it takes the night moths and other insects; and this is, I think, now the generally accepted theory.

Mr. H. Harries, of Brecon, when Grouse shooting near Crickhowell last year, found the egg of this bird in the heather on the I2th August. The Welsh is Troellwr, a whirller, a most expressive name. 


\section{WOOD PIGEON, Columba palumbus.}

Very plentiful, but the large flocks one constantly meets with in the winter must be visitors from other countries, and probably some from Herefordshire, where it breeds in great numbers. I think this bird is certainly on the increase here during the last few years, both as regards residents as well as visitors. Certainly one of the most interesting sights of this county was to see these birds arrive for the purpose of roosting in the Rock Wood close to this house. At about 3 in the afternoon of a November day the advance guard in the shape of a few stragglers would arrive, and after a little while a regular stream of pigeons would appear, and, with little break, continue until it was dark, when probably from 2000 to 3000 pigeons would have arrived and be roosting in the wood. Mr. Crawshay, who then preserved the Allt, only allowed them to be shot about three times in the season, and when this was done the fun for about an hour was fast and furious, the birds being most difficult to kill as they skimmed through and over the high 
trees. The best evening I ever had for three guns was I36, but of these Mr. Crawshay killed by far the most. The birds used to roost in the wood from October to March, and in April only a few were left. I have no doubt many, if not most of them, were arrivals from the Continent. I may add that the Wood Pigeon breeds remarkably true to colour and $I$ have rarely if ever seen a pied or albino bird certainly not alive. The Welsh is Ysguthan.

\section{STOCK DOVE, Colımba rnas.}

Greatly increasing. It breeds in hollow trees in the Usk Valley, also near this house, and in the Aberedw Rocks on the Wye. Twenty years ago it was a most rare bird in the county and I hardly ever observed it. Now, however, it comes in to roost to the trees in and near the Rock Wood with the Wood Pigeons and a flock of about 80 were most of the past winter feeding on the turnips, etc., near Talybont. It is a very fast flyer, faster even than the Wood Pigeon, and I think a rounder and plumper bird, and can be easily distin- 
74 THE BIRDS OF BRECONSHIRE.

guished from that bird by its smaller size. Welsh, Ysguthell.

ROCK DOVE, Columba livia.

Uncommon. Mr. Crawshay has killed two in a stone-quarry near Cyfarthfa, just over, if not actually is, the county; they are all of the Columbido, the most difficult of approach and the most difficult to shoot. Indeed, the quantity of shot this bird will carry away almost surpasses belief.

TURTLE DOVE, Turtur auritus.

A summer visitant, but in spare numbers. One place in the county where I usually notice it is on the large flat tract of land between Three Cocks and Boughrood the property of Lord Tredegar. I see it also on Newton Farm, near here, and it is in greater numbers than formerly. Welsh, Turtur, probably from its note, whence evidently its name of Turtle.

PHEASANT, Phasianus colchicus.

I cannot say when the Pheasant was 
introduced into Wales, but probably it soon spread from the large woods of Herefordshire until it established itself in the Great Forest of Brecon. It seems to do very well here, bearing severe cold with impunity. One of the largest Pheasants I have ever seen was a cock of the old-fashioned colchicus type, killed in 1879 in Lord Hereford's preserves at Tregoyd, by my friend, the Rev. John Bowen, the Vicar of Talgarth; it weighed 3 lbs. ro ozs., and measured $2 \mathrm{ft}$. IO $\frac{1}{3}$ ins. from tip of beak to tail; it was a very old bird. But the largest bird of all was one killed on Col. Morgan's Estate at Cilhowey by the late Major Bargrave Watkins, a few years since. It was a cock and evidently a first cross between Colchicus and Torquatus it having the ring only half-way round its neck. I weighed it the morning after it was killed and it then weighed $41 \mathrm{bs} .2 \frac{1}{2}$ ozs. It was preserved and is now in Col. Morgan's possession. It was a wild bred bird. I think that the buying of eggs to rear pheasants has to a great extent re-introduced the old English pheasant (Colchicus) into this county besides having a most beneficial 
effect on the size of the bird generally by introducing fresh blood.

The Chinese torquatus, with the white ring round the neck, is of comparatively recent introduction here, and is invariably smiler. Many white and pied birds have been killed in different parts of the county, at Clyro, and elsewhere. A beautiful pied hen, an old bird, was killed near Brecon in I88I. Indeed, of all the game birds, there is none that seems so peculiarly liable to sport white feathers, either in a greater or less degree, than the Pheasant. I fancy that the reason is partly that no fresh blood is introduced, and the birds are naturally weaker. On the other hand, my father had in an aviary at Chippenham, Wilts, a pure white cock Pheasant and two pure white hens, as well as a parti-coloured hen, all of good size and strength. Williams gives the Welsh for Pheasant as Iar wydd or iar goed, which is Wood Hen; but most Welshmen speak of the bird at the present day as Faisant, evidently an adaptation of its proper name. 


\section{BLACK GROUSE, Tetrao tetrix.}

Has always existed in this county, and I am glad to say, in spite of repeated thinnings, has, thanks to a few spirited landowners, considerably increased during the past thirty years. In I88I several brace were killed in one day on the Marquis of Camden's property, near Trecastle. Sir John Dillwyn Llewelyn also has a good many; and on Lord Tredegar's, Lord Glanusk's, and Mr. WilliamsVaughan's hills there is a fair stock of birds. In 1896 the latter gentleman killed seven old black cocks the same day on his Breconshire property. What a pity that they cannot have one year's jubilee awarded them in this county, for its wet-bottomed woods of alder and birch bordering our heathy hills are in every respect exactly suited to their habits; and their beauty as game birds must be appreciated by every true sportsman. The many "Black Cock" Inns that are scattered through Breconshire and South Wales are to a great extent evidence of their former occurrence here. Welsh, Ceiliog du or Ceiliog $y$ mynydd, cock of the hill, the last very 
appropriate.

RED GROUSE, Tetrao scoticus.

Still fairly plentiful on our heathercovered hills, and, for the reasons mentioned in the last paragraph, greatly increasing of late years. On the Eppynt Hills, Sir John Dillwyn Llewelyn and another gun killed, to the best of my recollection, some years since, thirty brace on the first day of the season; but his hill is a very extensive one, and he is too good a naturalist and sportsman to kill them down too closely. The same remark applies to Lord Glanusk and Mr. Williams-Vaughan, who have a fair stock. On the hills between Devynnock and Penwyllt the Grouse have greatly increased, and where a few years ago one could only see four or five birds, one may now see several packs. On one of these hills, in I88o, I and another gun killed five brace in September after the usual Grouse-shooting had taken place; and I am told they are now more plentiful still, such are the excellent effects of a little preservation. On the same hill on the I3th 
August, 1888, twenty-five brace were killed by four guns. I omitted to add that Grouse are plentiful on Lord Tredegar's excellently-preserved manor near the 'Storey Arms,' and on the Marquis of Camden's property near Trecastle.

A most curiously coloured Grouse was killed by Mr. Rees Williams of Brecon in the latter end of August, I89r, on the Friddyllt Grouse Hill, Merthyr Cynog. Its wings were extremely long and it was more like a Partridge than a Grouse in colour on various parts of its body. It was pronounced a cross between a Grouse and a Partridge, and also a cross between a Pheasant and a Partridge by several who observed it, but both the late Lord Lilford and Professor Newton, to whom I sent the Bird, pronounced it an abnormally coloured Grouse. It fetched nearly $£ 3$ at $\mathrm{Mr}$. Williams' sale and there was considerable competition for it. It is, however, well worth noticing in a work like the present. The Welsh for Grouse is Grugiar.

GREY PARTRIDGE, Perdix cinerea. Still common, I am happy to say, 
although they have, I think, been shot down much too closely in various localities. This should not be, as a better Partridge country than that round Brecon it is almost impossible to conceive. Birds having a white horse shoe seem to be on the increase during the past few seasons. Welsh, Petrisen.

\section{RED-LEGGED PARTRIDGE, \\ Perdix rufa.}

Almost unknown. About six or seven years ago a young bird was killed at Scethrog, near Brecon, by the late Mr. Williams, of Manest, in a turnip field. About six months afterwards, a gentleman living in Ashbrook Place, Brecon, on going into his garden, saw something running along the ground, and, it being late in the evening, he succeeded in catching it, and sent for a well known sportsman to look at it; he at once pronounced it to be a Red-legged Partridge, in excellent plumage, and no doubt a bird bred in the county ; it lived for four or five days, but its extreme wildness caused its death. He afterwards related the cir- 
cumstance to me. Mr. Williams thought that Mr. Alfred Crawshay, of Llansaintffraed, turned out a couple of Red-legged Partridges about a year previously, and that they must have hatched a small brood. In the autumn following, he believes, there were four or five young ones, and surmises that the bird he shot and also the one caught in Brecon were two of them; the remainder were not seen afterwards. Mr. Williams was an indefatigable sportsman, and had shot over the greater part of the county for more than forty years; and these were the only two he had ever seen or heard of as being killed; it justifies my including it, however, in my list of the birds of our county. Since writing this, I hear that Sir John Dilwyn Llewelyn killed another in the parish of Garthbrengy, near Brecon, in 1896 or I897. I have no doubt but that this is a genuine instance of its extension westward which it has been doing for many years. For instance it was unknown in Wiltshire thirty years ago, now it is common in many places in North Wilts. 


\section{QUAIL, Coturnix vulgaris.}

An occasional visitor. A friend of mine, shooting near Brecon some years since, flushed a small bevy when Partridge-shooting, but thought at first they were "squeakers"; he, however, followed them up, and killed three of them. At another time I saw a single bird on the hill near Devynnock, and another was killed not far from Llanwrtyd, at Cynghordy, by that excellent sportsman, the late Mr. Henry Gwynne-Vaughan. Mr. Williams-Vaughan also saw three or four near Trebarried some years since, but, after flushing them once, failed to rise them a second time; and Lord Glanusk also has sent me word that once he shot two brace of Quail at or near Glanusk Park. The late Mr. Williams of Manest told me that they were more plentiful here during the Franco-Prussian War than in any other season, and suggested that the constant firing which occurred at that time in France drove them over; he then killed several brace. In I880, I am informed, a brace of Quail nested near Bolgoed, Brecon, but did not hatch, in consequence, I imagine, of their 
THE BIRDS OF BRECONSHIRE. 83

being disturbed. I believe the late Col. Morgan, of Bolgoed, had one of the eggs. From the above, it will be seen that they are still somewhat uncommon with us. In the year I893 Mr. A. Crawshay killed six at Llanthew and six on Scethrog-near here. Welsh, Sofiar, a bird of the stubble; or Rhegen $y r y d$.

Before concluding my notes on the game birds, I must add that a few years since two very curious hybrids were killed in the neighbourhood of Builth-a cross between the Pheasant and Black Grouse, by the late Mr. T. Price of Builth. Both have been preserved, and are now in the possession of his daughter in Brecon; they partake of the shape and plumage of both parents in a marked degree, and the cross is distinctly visible; they are apparently birds of the year, and have been most excellently reproduced from a photograph as a frontispiece to this work.

Another of these most interesting birds was killed on the and December, I893, by Mr. A. Crawshay at Llansaintfraed whilst feeding among the 
84 THE BIRDS OF BRECONSHIRE.

Pheasants. It was a perfect Hybrid Pheasant and Black Game. It resembled the Blackcock at first sight, only it was much larger; indeed it was exactly half Pheasant and half Black Game even to the legs, which were feathered half-way down. It was nearly black in colour but in the light the feathers were all bronzed. The head was like a Pheasant in shape but dark in colour though lighter behind the eyes, whilst the tail coverts, tail, and entire wings were greyish brown like a Pheasant, and were much longer than a Blackcock's, but without the curl in the tail. Except that it was older and larger it exactly resembled those before alluded to as being killed in the neighbourhood of Builth. It is now in Mr. Crawshay's collection. It would seem, therefore, that to a certain extent these hybrids between Black Game and Pheasant breed true to feather and colour.

The subject of wild bred hybrids is most interesting. I believe them to be extremely rare, and generally, if not always, produced through either one or the other of the parent birds being 
THE BIRDS OF BRECONSHIRE. 85

unable to obtain a proper mate of its own species. Nature runs strictly in her own allotted grooves, and it is only when she is unable to do so (as in the present case) that the survivor seeks for a mate usually allied as nearly as possible to his or her own species, the result being hybrids incapable of breeding inter se.

\section{COLLARED PRATINCOLE.}

Glareola pratincola.

One of these curious birds was seen near Hay, in Breconshire, some time since by the brothers of the late Mr. Baskerville, of Clyro Court. They are quite certain it was the Collared Pratincole, for it alighted several times, and allowed them to walk close to it. They knew the bird well, as they had both been stationed in South Africa, where they had often observed it.

\section{THE STONE CURLEW,}

\section{Edicnemus crepitans.}

This bird is almost unknown with us, and I have never seen it, although one 
would imagine that our hills were well suited to its habits, but Mr VenablesLlewelyn writes me that he believes he has seen one on the Drygarn Hill, above Llanafanfawr, but he was never quite near enough to be absolutely certain. Mr. Howard Saunders rightly remarks of this bird, that west of Herefordshire it is almost unknown.

GOLDEN PLOVER, Charadrius pluvialis.

Resident with us; it breeds sparingly on some portions of the Eppynt hills, and on the hills between Llanafanfawr and Nantgwyllt it breeds in some numbers. It also breeds on the range of hills stretching from the Sugar Loaf, near Llanwrtyd, to Llanafanfawr. Occasionally it comes down to the lowlands, but very seldom; it is essentially a bird of the hills. In the severe winter of I880 large flocks frequented the fields at Newton, close to Brecon, and remained for a considerable time. Welsh, Rhostog euraidd, or Bronddur Troynau; others, Chwilgorn-y-mynydd.

LAPWING, Vanellus cristatus.

Very common with us all the year 
THE BIRDS OF BRECONSHIRE. 87

round; it breeds all over the county. The Welsh call it by the appropriate name of "Cornicyll" (the bird with the little horn).

\section{DOTTEREL, Eudromias morinellus.}

A friend of mine has seen this bird near Abergwessin, and I was recently shown a beautiful stuffed specimen that had been shot in the adjoining county of Cardigan. It is very rare in the county.

RINGED PLOVER, AEgialitis hiaticula.

Occurs occasionally at Llangorse Lake. One was killed there by my son J. Vaughan Phillips on the IIth August, I89o. There are a few little pebbly beaches there which attract it but I have never seen it elsewhere in the county.

TURNSTONE, Strepsilas interpres.

Only an occasional visitant to this county. One was killed at Llangorse some years since by Cross, keeper to Mr. Gwynne Holford, and another was killed out of a little party of four on the hill 
at Merthyr Cynog in August I896 by Sir John Dilwyn Llewelyn, who kindly gave me this information.

\section{GREENSHANK, Totanus glottis.}

Also very rare. I have seen it on the banks of the river Usk, about two miles above Brecon, running along a little sandy beach. I was fishing at the time, and watched it for some minutes before it was aware of my presence, when it quickly flew away. The late Mr David Thomas, of Brecon, had a stuffed specimen in his collection that was killed near this town. A beautiful specimen of this bird was killed by my youngest son at Llangorse Lake on the Ist September, I897. I have it now in my possession.

COMMON REDSHANK, Totanus calidris.

Very uncommon with us, and, in fact, is considered quite a rarity; occasionally, however, one is killed. In the autumn of I880 one was shot, by a gentleman living in Brecon, on the Eppynt Hills : it was a young bird of the year, and 
THE BIRDS OF BRECONSHIRE: $\quad 89$

it is therefore quite possible that it was bred somewhere near the spot where it was killed. It must have bred at Llangorse Lake as one young one and one old one were observed there on IIth and 16th August, I89o. It has also been obtained by Capt. Sandeman in the neighbourhood of Crickhowell. The Welsh name is coes goch (red-leg).

GREEN SANDPIPER, Totanus ochropus.

This beautiful little wader occurs every spring and fall on the Usk, near Talybont, and has often been killed there. Last year a pair were constantly seen in June on the river close to this house. I myself did not see them until July 2Ist, 1898, but when following the otter hounds four flew up the river about a mile higher up than the spot where I had seen the old birds. They were very wild and flew high but this was caused by the hounds being in full cry at the time. Shortly afterwards, what I imagined were the old pair flew up the river close before us and I pointed them out to a friend who was with me. Whether these were two of the four that 
had flown up from the same place before I cannot say, but I think they were as they were flying in the same direction. Taking all things into consideration it seems to me probable that the Green Sandpiper bred with us last year, although I have no more positive proof of it.

\section{CURLEW SANDPIPER, Tringa subarquata.}

One of these birds was killed on the Eppynt Hills in the month of September I 892 by Capt. Hotchkis. He kindly sent it me and I had it stuffed. It is now in Mr. A. Crawshay's collection.

\section{PURPLE SANDPIPER,}

\section{Tringa maritima.}

A specimen of this little wader was picked up dead under the telegraph wires on the railway between Brecon and Talyllyn in the year 1887. The finder had it stuffed and brought it to me for identification.

COMMON SANDPIPER, Tringoides hypoleucus.

As its name denotes, is most common 
THE BIRDS OF BRECONSHIRE. $9 I$

with us, especially on the banks of the Usk and Wye, where it breeds; it is also to be found on most of our smaller streams. It is very tame during the breeding season, and its elegant flight and twittering wailing cry form a pleasing accompaniment as with rod in hand one follows the windings of our beautiful rivers. Welsh, Pibydd-y-trath.

\section{KNOT, Tringa canutus.}

The only instance I can quote of its occurrence here is a specimen killed near Hay, most probably an exhausted migrant; also one reported as seen in September last year on the drive at Bolgoed.

DUNLIN, Tringa alpina.

Occurs very occasionally at Llangorse Lake and on the River Usk. One was killed there IIth August, I890, by my son J. Vaughan Phillips; another on the 29th December, 1890, at Vennyfach, near Brecon; and four others on the Usk at Llansaintfraed by Mr. A. Crawshay. 


\section{GREY PHALAROPE, Phalaropus fulicarius.}

One killed on the Wye, near Glasbury. I have seen this bird, which has been preserved; it is in winter plumage.

WOODCOCK, Scolopax rusticola.

Our county has long been celebrated for its Woodcock-shooting, but alas, it is but too true that the Woodcock gets scarcer and scarcer each succeeding year. I think the last hard winters have considerably lessened their numbers. The season I88I-82 was the worst for Woodcocks I ever remember. In beating a large cover in February, 1882, I only flushed a single bird, where in years past I have often found a dozen, it being a favourite place for them early in the year. I think it may possibly breed occasionally with us as some few years since a young Woodcock was picked up near Talgarth some time in the summer not quite fully fledged and reported to me at the time. Welsh, Cyffylog.

GREAT SNIPE, Gallinago major.

Occurs oftener with us than is gener- 
ally imagined, being regarded by many people as merely a very fine Common Snipe. About six years ago I flushed what appeared to me a very large Snipe on a bog on the Eppynt Hills. It made no noise on rising, and on my missing it, flew steadily and slowly for about one hundred yards, when it pitched again. I killed it on flushing it the second time, and found it to be the Great Snipe, a bird of the year. On the large bog at Onllwyn in September, I88o, I had just knocked down a Common Snipe, which my retriever was bringing, and on taking it from her a splendid Great Snipe rose at my feet, and flew, very like a Woodcock, slowly away; all my efforts to find it again were unavailing, although it must have settled close by. Mr. Alfred Crawshay has killed this bird at Llangorse in August, 1876 , and a man at Senny Bridge, who showed me a particularly large Snipe that he had killed near Cray some years ago, seemed quite astonished when I informed him that it was a Great Snipe. Welsh, Giach Mazer. 
94. THE BIRDS OF BRECONSHIRE.

COMMON SNIPE, Gallinago media.

Breeds commonly on the various bogs on all the hills in the county. When flapper shooting on a large bog in the neighbourhood of Devynnock on August Ist, I88I, I killed seven Snipe, all young birds, The Snipe, however, on the whole, are not nearly so numerous in the winter season as they were. As with the Woodcock, the two last severe winters we had played sad havoc in their ranks. They are plentiful on the many bogs on the Eppynt Hills, and I know nothing more delightful than to wander with dog and gun on a fine November day, after rain, over these beautiful hills, now picking up a few Snipe, then a Duck or Teal, sometimes a Woodcock or two, often a Golden Plover, and listening to the cry of an old cock Grouse, as he springs whirring up far out of reach. The largest bag of Snipe I ever made on these hills was seven couple in February. The Welsh name for the Common Snipe is giach, and as pronounced in Welsh admirably expresses the sound it makes on rising. I am informed that a 
THE BIRDS OF BRECONSHIRE. 95

sportsman killed, near Builth, twenty couple of Snipe on the Ist of August last, but this I should consider exceptional.

JACK SNIPE, Gallinago gallinula.

Very common with us, especially during the season I88I. I think this bird stands the severe cold better than the Common Snipe, and is, as its French name implies, of a more sluggish nature. A gentleman in this town who had been shooting over one of the large Snipe bogs near Trecastle in December, I889, told me that his party had moved from thirty to forty Jack Snipe in one day. This little bird has a very strong scent; most dogs hunt them with eagerness, and pointers and setters usually stand them with great staunchness. Welsh, some call it Giach bach, which is simply Little Snipe.

CURLEW, Numenius arquatus.

Breeds very generally with us on most, if not all, of our hills, and in many swampy places, making its appearance with great regularity about 
the middle of March, and going away again-I think to the sea-side-before or by the ist September. Miss Lewis Lloyd, of Llandefaelog, told me that in I882 the Curlews came to their breeding places earlier than their usual time. They are certainly on the increase, and I think that being protected in this county from the Ist March to the ist August may, in a great measure account for this. The Curlew is a bold bird in the breeding season, when, like many other birds, it seems to throw off its exceeding caution. I once saw a Curlew make a very determined attack on an old Carrion Crow that was probably on the look-out for one of its young ones. The Crow stood no chance against the Curlew, with its grand free flight, and was soon beaten off and pursued until both were close to me. The exceedingly appropriate name of the Curlew in Welsh is Chreibanog-ymynydd (the whistler of the mountain), and in ancient Welsh, Gylfinhir (Williams).

THE WHIMBREL, Numenius phaopus, is unknown in this county. 


\section{COMMON CRANE, Grus cinerea.}

Although now, of course, extinct, yet I think it mnst have formerly occurred here in years gone by in some numbers, from the fact that the Welsh, both here and in Carmarthenshire, invariably call in English, the Heron a "Crane"indeed I never remember a native call the Heron by any other name. The Welsh for Crane, as given in Richards' Dictionary, is Crychydd, but he does not apply this word to the Heron, although two of the other names of the Crane and Heron are identical in Welsh; still I always hear the Heron called Crychydd by the Welsh both here and in Carmarthenshire, and this would lead one to believe that the name of the Crane had in some way descended to the Heron, and although this is far from conclusive as to the former occurring here, still I think it is well worth noticing.

HERON, Ardea cinerea.

Very general everywhere on all our rivers and streams, It breeds sparsely in scattered pairs all over the county; 
sometimes there are two or three nests in the vicinity of each other, but we have no regular heronry in the county, and numbers must go elsewhere to breed. Formerly there was a heronry at L/wynwormwood Park, near Llandovery, Carmarthenshire, about twenty miles from Brecon, as the Crow-or rather the Heron-flies, but from some inexplicable cause, and without any apparent reason, about thirty years ago this heronry suddenly broke up into two parties, one going to Neuadd-fawr, Cilcwm, near Llandovery, the residence of Mr. Campbell Davys, and the other, and smaller portion coming to Bailyddu, Llandilofan, in the county of Brecon, where, however. they did not stay long, but no doubt gradually distributed themselves over the county. The distance from L1wynwormwood to Neuadd would be about six miles, and to Llandilofan about twelve miles. I am indebted to the late Col. Jones, of Velindre, Llandovery, for the above interesting particulars. The severe weather, of January, I88I, was most fatal to the Herons. In looking for Woodcocks in that month, on one of the coldest days I ever 
THE BIRDS OF BRECONSHIRE. 99

remember, I moved a splendid cock Heron from a spring, or as it is called here a "soak," near the Gludy Lake. Happening to be in the same place a few days after, I found one (probably the same bird) dead from starvation. About the same time I also saw another Heron dead from the same cause on the banks of a pond at Penlan, close by Brecon. A very small colony of Herons have bred in a wood near Senny Bridge for many years, but their nests never seem to increase beyond half-a-dozen. These birds, I am glad to say, have a very easy time of it here, not being often molested, as if killed they are seldom or ever eaten. A few breed every year at Buckland, the seat of Mr. Gwynne Holford; another small colony exists at the Loscoed, near Devynock; and there are also a few breeding every year in the larch wood close to Tregunter. My brother-in-law once killed a Heron in a field close by a stream and found his crop filled with field mice-a somewhat curious repast for a fish eater. I should add that some ten years ago my second son killed in the winter one of the largest Herons I have ever seen on the 
sewage farm, near Brecon. This was a very old cock bird with the longest crest and brest plumes I have ever observed, and its plumage was otherwise perfect. It now adorns my small collection of Breconshire birds.

\section{PURPLE HERON, Ardea purpurea.}

Has once been killed in the county, near Talybont. The gentleman who shot it told me there were three together on the River Usk, near this place. This specimen, which has been preserved, I have had the pleasure of inspecting, and a beautiful specimen it is.

\section{SQUACCO HERON, Ardea comata.}

One of these unusually rare visitors was shot by Captain Hotchkis on the River Wye, near Hay, in Breconshire, on May 3rd, 1867 , and is now in the collection of the late $\mathrm{Mr}$ Baskerville, of Clyro Court, Hay, who kindly favoured me with these particulars.

BITTERN, Botaurus stellaris.

If ever there was a county that formerly echoed with the "boom" of the 
Bittern, it must have been Breconshire; now, however, it is scarce. Still a great many have been killed in various parts of the county from time to time. Mr. Gwynne Holford shot one at Llangorse Lake some years ago, Mr Rees Williams has killed it on the Usk, and $\mathrm{Mr}$ Crawshay at Llangorse, and several have been killed and seen there since. Near Llandulas Church, situate in the most wide and desolate part of the county, and which was hunted by the late Col. Jones, of Llandovery, with his excellent pack of harriers, there are several rushy bogs, and not long since, in one of these, the Colonel when hunting constantly flushed a Bittern; it did not fly far, but settled again close by. The feathers of this bird were formerly-and I believe still are-in great request with anglers for making a particular salmon fly. The Welsh for Bittern is, like most other Welsh names, wonderfully descriptive, viz., Aderyn-y-bwn (the bird with the hollow sound), from "bwmp" a hollow sound; hence probably the English word "boom," so generally applied to the noise made by the bird. 
The Little Bittern, Botaurus minutus, so far as I can learn, is unknown in this county, for after numerous enquiries, I am unable to record any instance of its occurrence here. It is possible, however, that being only an occasional summer visitor, it has, from the nature of its haunts and its shy retiring habits, hitherto escaped observation. Saunders says it often escapes notice by remaining motionless with outstretched neck and bill pointing upwards-resembling a dry stick or reed whence its appropriate Dutch name - Woud - aapje, meaning "Wood ape."

\section{WATER RAIL, Rallus aquaticus.}

Remains with us all the year round, and may be very generally found in all the marshy places of the county; it is seldom seen, on account of its skulking habits, but is far more common with us than is generally supposed. It counterfeits death exceedingly well. In shooting round a lake near Brecon, I flushed a Water Rail close to me. I fired, and down fell the bird. On picking it up, it lay in my hand for some 
minutes motionless, and to all appearance dead. I was looking for a shot-mark, when suddenly, as I looked away for a moment, without the slightest warning, it flew off. I was so surprised that I could hardly believe my eyes. My dogs moved the bird twice afterwards, but I gave the clever little fellow the liberty it had so well earned. The late Rev. Mr. Marsh, of Sutton, Benger, Wilts., used to say that dogs hunt the Water Rail with greater avidity than any other water bird, when once it has been killed to them; and I have found this to be the case, several dogs I have had taking the greatest pleasure in hunting them. Some years ago I had a fine stuffed Bittern with a skeleton of a Water Rail which had been taken from its crop after it had been killed. The cry of this bird in the breeding season is loud and resonant and when once heard can never afterwards be forgotten. The literal Welsh is Ysgrech $y$ dwr.

\section{I,ANDRAIL, OR CORN CRAKE,}

Crex pratensis.

Fairly plentiful, but I have never seen 
IO4 THE BIRDS OF BRECONSHIRE.

them in any numbers. In August and September they are often found on the hills, where I think they resort before returning. They are not nearly so plentiful with us as in England, and I think have decreased in numbers of late years. Here again the Welsh name, Ysgrech $y$ gwair (the screamer of the hay), is most impressive, the word ysgrech, as pronounced in Welsh, being a good imitation of the cry of the Corn Crake, and preferable in this respect to our word "crake." When Grouse shooting in August 1897, at Merthyr Cynog, in company with my brother-in-law, Mr. A. Gwynne Vaughan, he shot at and winged a Landrail. It fell in some reeds and ran, and the pointer drew it for a considerable distance. It then set up a prolonged screaming and I picked it up whilst so doing. The noise it made was shrill and startling and quite unlike the ordinary "Crake." Although I have killed many of these birds I have never heard one utter a sound except in the breeding season.

SPOTTED CRAKE, Crex porzana.

A regular visitant, but very local. On 
many large bogs in this county it is never seen, on others it is invariably to be found. On the numerous bogs on the Eppynt Hills, over which I had the privilege of shooting for many years, I have never seen it, whilst on the Trath, a large bog on Mynydd Illtyd, near Brecon, it is to be found every year; but the favourite spot for them in this county is in the large bog at Onllwyn, and here in the early part of the shooting season I invariably used to flush several, and many breed in this place. I one day flushed six and killed four, three of which were birds of the year. The station-master who was then at Onllwyn informed me that there were two broods of them hatched in that part of the bog close to the station that year. This is an enormous bog, the middle of it being very deep, and about half a mile of it absolutely unapproachable, thus forming a secure retreat for many waterbirds. From the thickness of the reeds it is almost impossible to beat this stronghold of the Spotted Crake with dogs, and many have been lost in attempting it. I generally find them where a warm spring runs in a little rivulet through 
the centre of a bog, and they greatly frequent this part. The flight of the Spotted Crake varies greatly, sometimes, like the Moorhen, flapping slowly out with its legs hanging straight down; at another time tucking them up under their bodies, and flying with all the speed of, and very similar to, a Quail, and the more the autumnal season advances the stronger I fancy they fly. I have never seen but one after October here, and that was I think in the latter end of November, on the Onllwyn bog. $I$ once had one alive in my hand, a winged bird that my dog caught before it could escape into the reeds; its eye was a brilliant olive-green, and exactly matched the colour of its legs. I mention this because bird-stuffers invariably return you the bird with a red eye; this the bird never has but I think probably the colour of the eye may vary from that found in birds of the year to possibly hazel in older birds. For instance the colour of the eye of the young Moorhen is for the first six months, when it is in its brown plumage nearly the colour of its leg, but this afterwards changes to red in the grown up bird and 
it must not be forgotten that the colour of the eyes and legs often assimilate the adult Moorhen having a vein of red just where the feathers cease on the leg. Hawks too have generally yellow legs and yellow eyes, and there are many other birds where the colour of the eye and leg is nearly the same. Like all the Crakes, it is very difficult to flush the second time, but dogs hunt it with the same eagerness that they do the Water Rail. It has been killed on some of the bogs near Cray, and its nest and eggs have been taken on the Trath, near Brecon. Sir John Dilwyn Llewelyn tells me that in the fall of the year he can at any time move three or four in some bogs in Glamorganshire. Of course, as in the process of time many of our larger bogs are drained, the area used by this bird must necessarily get smaller until it ultimately has no place to breed, but I hope that the county will yet afford this graceful and elegant little visitor a safe breeding place for many a year. May not its exceeding rarity in many parts of England arise from this cause ? The late Rev. Mr. Marsh, who has one of the finest col- 
lections of British Birds in Wiltshire, told me that he had seen it twice in his life, and those were days to be marked with a white stone. I never kill one now except to oblige a brother naturalist. I may add that I have never seen it on any of the bogs near Llanwrtyd, which bears out my observation as to its partiality for particular localities. It has also been obtained near Hay, on the other side of the county. I saw one killed in a bog in Ayrshire at the end of November last year.

MOORHEN, Gallinula chloropus.

Very general everywhere, except on some of our rivers and brooks. Though plentiful on the Brecon Canal, and on all our lakes and ponds, especially Llangorse Lake, it is hardly ever seen on bogs on the hills, preferring water where it can swim and feed in quietude, and this it is unable to do on rapid streams. It is very common in the Rock Pool on the Usk under this house, and as the birds are never disturbed, they get very tame, sometimes even mixing with poultry. I may add that this bird is very 
THE BIRDS OF BRICONSHIRE. IO9

little liable to albinism, and a White Moorhen is almost unknown. Two occurrences, however, one only partial, have been reported me from Wiltshire. Welsh, Dyfriar, Waterhen.

\section{COOT, Fulica atra.}

Very common on Llangorse Lake, where it breeds, as it does also on a few other smaller lakes in the county; but the large number of Coots that appear in the early part of the winter are migrants from other parts. I think it is increasing of late years, and since the Gludy Lake, near Brecon, has been looked after, it has become much more numerous there. This would also be the case at Llangorse Lake, but for the constant fusilade which takes place there every year directly the shooting season opens (August), and which must inevitably drive away every bird from its waters. It is worth remarking that on our deep hill-bogs the Coot is never found, and only occasionally the Moorhen. On the Onllwyn Bog, before mentioned, I have never seen either of these birds, and this is, I should think, the largest and deepest bog 
IIO THE BIRDS OF BRECONSHIRE.

in the county, as well as the most dangerous. The Welsh do not seem now to distinguish this and the last bird, having the same name for both.

WILD SWAN, Cygnus musicus.

At one time probably visited Llangorse Lake regularly in severe weather. A fisherman who frequented the lake saw six there one winter's morning, but had never observed any since. About twentyeight years ago, in riding down the beautiful valley of the Usk towards Talybont I myself saw a single Swan, probably a wild one, flying very high in the direction of the sea. The grand and powerful flight of that snow-white bird, cleaving its way through the air, I shall not easily forget; It was like a streak of silver in an azure sky. In the hard winter of January, I89I, Capt. Hotchkis saw three Wild Swans on the Wye, near Builth, and although he stalked them for an entire day he failed to get one. They remained in that locality for some days. Six were also seen at Llangorse Lake about the same time and reported to me. Welsh, Alarch greyllt. 
THE BIRDS OF BRECONSHIRE. III

\section{GREYLAG GOOSE, Anser ferus.}

Only occasionally seen in severe weather, and then passing over at a great height. A few have been shot from time to time, and a friend of mine tells a good tale of a gamekeeper of his seeing some Geese in very hard weather in a meadow, and in an excellent position for stalking them, but after watching them for some time he came to the conclusion they were tame birds until undeceived by their flying away. Mr. Crawshay has also killed it on the Usk. Welsh, Groydd Groyllt.

\section{BEAN GOOSE, Anser Segetum.}

Occurs sometimes on the river Usk near Talybont. Mr. A. Crawshay killed two there in January, I890, and there were two others in the same locality. My introduction to this bird was so interesting that I think it may be worth relating. It was in January, I894, and Mr. Crawshay and myself had been ferretting all the morning, but the rabbits had not been bolting well, and after lunch there remained two hours of daylight. So wishing to finish the day's 
II2 THE BIRDS OF BRECONSHIRE.

shooting, we started down towards the old river which consists of stagnant pools covered with rushes, about two miles from this place. Unfortunately we took no man with us, but only an old retriever. On reaching the first pool, about I4 wild duck got up just out of shot and pitched in the very middle of a large field that had the reputation of being a favourite field for geese in by-gone years. Whilst watching the duck, we were surprised to see seven Bean Geese, headed by a fine old Gander, flying slowly after them and pitch in the same field. Whilst their numbers were further increased by a flock of Peewits who shortly afterwards joined them. There they were quite safe in the middle of the big field, so near and yet so far, with no possible means of approach, so we agreed to walk up to them, some distance apart, in the hope, a false one, that one or the other might get a shot at the Geese. On our way, however, we flushed a nice little lot of Teal which settled again close by, out of which we got three, afterwards killing three Wild Duck, three Snipe, and a rabbit, when the light failed. To our great surprise, however, the Geese seemed 
reluctant to leave the field and kept on flying about backwards and forwards, seemingly very tired, but taking good care to keep just out of gunshot. Next day was Sunday, so hoping that as they had not been much disturbed they might still be there on the Monday, a start was made, but not a bird was to be seen. I have mentioned this little circumstance principally to show what a curious collection of wild fowl may sometimes be seen together even inland without any apparent cause. I should add that the weather was mild and open and we "wisely" predicted a speedy change, but no such change came, and I can only suggest that the Geese had just arrived and were resorting to their favourite field, and being thoroughly tired were loth to leave it. Had we had someone to attempt to "drive" the birds over us, I think we might possibly have secured one or two.

\section{WHITE FRONTED GOOSE,} Anser albifrons.

Three were killed near Llangorse Lake in the winter of 1888 by Mr. Adney, who 
II4 THE BIRDS OF BRECONSHIRE.

very kindly sent me one for identification. He saw several on a small pond near the lake and killed two, and hit another hard, which he found dead on the lake next morning. Mr. A. Crawshay has also killed this bird near Talybont.

BERNICLE GOOSE, Anser leucopsis.

One was killed on the Usk at Talybont in $\mathrm{I} 882$ by Mr. A. Crawshay. This is the only occasion I have heard of its occurrence in the county.

\section{PINK FOOTED GOOSE, anser brachyrhynchus.}

One was killed near Builth in the year I89o. It is, of course, only a rare straggler.

\section{BRENT GOOSE, Anser bernicla.}

I have received reports of individuals of this species having been killed in this county, but I imagine they must have been exhausted birds detached from flocks, or, what is more probable, driven inland by the violence of some storm, the Brent Goose being essentially a bird of the sea-coast. 
THE BIRDS OF BRECONSHIRE. II5

CANADA GOOSE, Anser Canadensis.

Captain Swainson kindly writes me that he saw a small flock on Llangorse Lake in January I89I. Some Brent Geese were with them. It was very hard weather at the time, which enabled him to get within 150 yards of them, so that he could see their white gorgets. Whether these birds had escaped from private waters or not I am unable to say.

SHELDRAKE, Tadoma vulpanser.

Has been obtained here from time to time, although rare. Three winters ago one was seen, close to this town, on the Usk, and others have been killed on the Wye. It also frequents Llangorse Lake from time to time; one was seen there on the Ist Sept., I898. Mr. Crawshay has also killed it. It is not generally a difficult bird to approach, and its bright colours render it very conspicuous. It breeds all along the sandy coasts of South Wales, and at Portskewett at the mouth of the Severn it may often be observed, as it is fairly plentiful in that neighbourhood. 
WILD DUCK, Anas boschas.

Common, breeding all over the county on the numerous hill-bogs, on the Usk near here, and in quiet places adjoining our streams. I have flushed a Wild Duck in a green lane not far from the Usk, and from her movements, as she declined leaving the place, allowing me to catch her, I am certain she had a nest in the hedge there, but not wishing her to forsake it, I did not further disturb her. A great many breed in the bogs about Devynock, and the large bog called the Trath, near Brecon, is a favourite place for them. Some years since, happening to be on the highest point of the hill near Merthyr Cynog, and walking over a small bog, an old duck suddenly rose near me, and looking down I saw a young one, quite grown and in full feather, squatting in a little "form" in the reeds, like a hare, its neck drawn back, its head resting on its back, and its tail up, evidently endeavouring to make itself look as small as possible. I put my hand cautiously down, and easily caught it, when it seemed all at once to 
develope into a full-grown, fully fledged Wild Duck, in excellent condition; so I and my old retriever, who evidently considered something unusual was up, beat the bog carefully, and before we left he brought me five more full-grown young ducks, which with the one I had caught myself, made no slight weight to walk down to the shooting-box withtwo miles off and more. To this day I cannot make out why they did not fly, as it was the first week in August. The Wild Duck is on the increase here, and I account for it from the fact that so many young birds are too strong on the wing to approach on the Ist August (the "close time" for wildfowl in the county being from the Ist March to that date). Perhaps it would be better to make it the Ist of February, for if the weather is mild the ducks are generally paired during this month. Welsh, Hroyad zeyllt.

GADWALL, Anas strepera.

Six were seen on a little pool at Llandilo Graban, Radnorshire, close to the borders of this county, by Mr. H. N. 
II8 THE BIRDS OF BRECONSHIRE.

Ridley, of the British Museum, in August, I880, and were reported by him to the "Zoologist." One, a female, was killed by Mr. A. Crawshay at Scethrog, on the Usk, in August, I885.

\section{SHOVELLER, Anas clypeata.}

Very rare. One has been killed on the Wye, near Hay, and Capt. Sandeman obtained another, a male, a few years ago on the Usk at Danypark, Crickhowell, on I6th February, I89I.

\section{PINTAIL, Anas acuta.}

The same remarks apply to this as to the preceding bird. One has been killed on the Wye, near Hay, and, with the last-named bird, was, I believe, in the possession of the late Mr. Baskerville, of Clyro Court, who kindly supplied me with the above information. I also, about twelve years since, saw a Pintail on the Gludy Lake, near Brecon, in company with a small flock of Wild Ducks. Some Welsh books give it as Llwybig.

WIGEON, Anas penelope.

Common in the winter on Llangorse 
Lake, where in hard weather it congregates in numbers, but is scarce elsewhere in the county. Occasionally a few visit the Gludy Lake, and a few frequent the Usk and Wye in severe weather. I have never seen it on any of the mountain bogs, and, I need hardly add, it never breeds with us. Welsh, Grwizell or Chwizes. Evidently this name is from the noise or cry the bird makes.

\section{TEAL, Querquedula crecca.}

Fairly plentiful with us, and breeding sparsely in several places in the county. I have found its young in a very small and deep pond called by us the "Teal Pond" on the Eppynt Hill, near Merthyr Cynog. They seem to have taken a great liking for this small pool, and I invariably found a flock there in the winter, and a pair nested there regularly. They breed in a large bog near Cray, on the Trath bog near Brecon, and on the large bog at Onllwyn, besides other places. I have little doubt that, if they had anything like quiet, they would breed at Llangorse in some numbers. They are occasionally plentiful there in 
I2O THE BIRDS OF BRECONSHIRE.

the winter, but I do not think these can be birds reared in the county. A few breed on the other parts of the Eppynt Hills. Welsh, Corhwyad (Williams.)

GARGANEY, Querquedula circia.

I have seen two, believed to have been killed on the Wye, near Hay. Another, a duck, was killed by Mr. Crawshay on the Usk near Talybont in the month of January, 1885 , and was reported by him to "The Field," and is at present in his collection.

\section{POCHARD, Fuligula ferina.}

Occurs on Llangorse Lake in the winter months; it has also been killed on the Usk and Wye, but is very uncommon on both these rivers. Mr. A. Crawshay has killed it on the Usk, and my brother-in-law, Mr. A. Gwynne-Vaughan, killed a fine male on the Irvon, near Builth.

SOAUP, Fuligula marila.

A very rare duck with us, but visits us occasionally. Mr. Alfred Crawshay shot 
one on the Usk in I889. Some years ago I killed a Scaup under rather singular circumstances in Wiltshire. I kept some very small black East Indian ducks on a pond quite in the country: the man who looked after them told me that a strange duck was with them, but was very wild. I was returning from snipe-shooting at the time, and going to the pond the stranger immediately dived, and I killed it on its reappearance with a charge of snipe-shot, and found it was a female Scaup in perfect plumage. Doubtless it had mistaken the tame black ducks for a flock of its own kind. One was also killed at Llangorse Lake on the 28 Oct., I893, by Lieut. Armitage, and was identified by me; it was a drake.

\section{TUFTED DUCK, Fuligula cristata.}

Not nearly as rare as the preceding, though occurring here at intervals. One was shot on the Wye at Clyro, near Hay, and Mr. Williams-Vaughan has another in his collection that was killed in the county. The late Mr. David Thomas , had also a specimen procured on Ilangorse Lake, where years ago I have no 
doubt our rarer species of ducks were more frequently found. Nine were killed in one day in January, I89I, at Talybont on the Usk by Mr. A. Crawshay. The late Major Bargrave Watkins also killed one near Brecon, and others have been killed on the Usk and seen by me.

\section{GOLDEN-EYE, Clangula glaucion.}

Not common. One has been obtained on the Wye, near Hay, and others by Mr. A. Crawshay on the Usk. It visits the Usk from time to time, principally in hard weather. I have killed it close to this house in a severe frost in 1896. It has also been killed near Brecon. Capt. Sandeman, of Danypark, Crickhowell, also writes me that he killed a pair right and left on the Usk, which runs through the park; and a pair were on the Rock Pool, close to my house, in January of this year, and stayed with us for some time.

\section{LONG TAILED DUCK, Harelda glacialis.}

One out of a pair was killed on Liangorse Lake on 27 th October, 1893, by 


\section{THE BIRDS OF BRECONSHIRE. 123}

Lieut. Armitage, and was brought to me for identification. He informed me that he had some trouble to kill it and the quantity of blood that came from it was surprising. It was an adult female and was duly preserved.

\section{COMMON SCOTER, EEdemia nigra.}

Occurs occasionally in the winter at Llangorse Lake and on the Usk. One, a young bird, immature, was killed on the Usk, near Brecon, on the gth January, r89r, by Mr. D. W. E. Thomas. Another immature bird was killed close to the town. It has also been killed near Talybont by Mr. A. Crawshay. In Welsh it is called Mor hwyad ddu, the black duck of the sea.

SMEW, Mergus albellus.

This pretty little bird sometimes visits Llangorse Lake, and also the river Usk. I have had one brought me that was killed there, and the late Mr. David Thomas, of this town, had a very good stuffed specimen obtained at the same place.

A beautiful male Smew, in the perfect 
I24 THE BIRDS OF BRECONSHIRE.

adult plumage that one so seldom sees, was killed on the Usk, near Talybont, on the 8th January, I89I, by Mr. A. Crawshay, and is now in his collection. $\mathrm{He}$ has also observed others there since.

\section{RED-BREASTED MERGANSER, Mergus serrator.}

Occurs very rarely with us in severe weather, both on the Usk and Wye. I have seen the skin of a beautiful male which was shot on the Wye, near Erwood.

GOOSANDER, Mergus merganser.

A winter visitant, though of more frequent occurrence than the last-named. From what I can learn, they were formerly often observed on the Usk in the winter season. The late Mr. Williams, when living at Manest, had often shot them there. Lower down the river, at Talybont, Mr. Alfred Crawshay has killed several female Goosanders and one male; and, still farther down, two or three have been shot by Lord Glanusk at Glanusk Park. They have also occasionally been seen and killed on the Wye. 
Mr. Crawshay tells me that he has seen a flock of twenty females fishing together on the Usk at Buckland but the males were scarcer. I see small flocks often in the spring near this house on the Usk, and it has been killed on the Wye, near Gwernyfed, by Col. Wood's keeper. Two, both females, were sent by the Colonel to me for identification. I need hardly add that it is an exceedingly swift flyer. Williams gives the Welsh, Hwyad ddaneddog.

\section{GREAT NORTHERN DIVER, Colymbus glacialis.}

Many years since the late Mr. Duncan, of this town, shot a beautiful male bird on Newton Pool, close to Brecon. The late Mr. David Thomas had also a pair from the Usk near Brecon. Mr. A. Crawshay has observed it at Llangorse, and in the winter of I88I one was killed there and two others seen. Some specimens have also from time to time been obtained on the Wye, near Hay and Glasbury. 
I26 THE BIRDS OF BRECONSHIRE.

\section{BLACK-THROATED DIVER, \\ Colymbus arcticus, and RED-THROATED DIVER, \\ C. septentrionalis.}

I have seen a Black-throated Diver, a stuffed specimen, believed to have been killed on the Wye, near Glasbury. An adult Cock in immature plumage but beginning to assume the black spots on the back was killed on Llangorse Lake on 27th February, 1892, by Lieut. Armitage, and examined by me. He told me there were a pair there, the other bird being smaller, but he failed to get it. Captain Hotchkis also secured a Red-Throated Diver on the borders of Radnorshire some few years since. It is very probable that occasional birds of both kinds very rarely visit us from time to time, but escape notice, and so are unobserved and unreported.

\section{GREAT CRESTED GREBE,}

Podiceps cristatus.

A special haunt of this bird is Llangorse Lake, where at one time it must have been quite plentiful. It is fairly 
common there, breeding regularly, but in no other place in the county that I am aware of. Its shy and retiring habits, its wonderful sight, and diving powers, have alone preserved it from extirpation; but with all these in its favour it often gets killed, as the many stuffed specimens both here and elsewhere so abundantly testify. Mr. Alfred Crawshay, shooting round the lake some years ago, noticing a great commotion in the reeds made by a Grebe, fired at it, and on rowing up, found he had killed a male and a female Great Crested Grebe and one young one, which at the time he fired must have been sheltering under her wings. $\mathrm{He}$ has had the three stuffed to commemorate the incident. It is a pity this bird should be killed, for on a large lake like Llangorse it would do actual good by keeping down the extraordinary number of small roach and perch that swarm there.

LITTLE GREBE, Podiceps minor.

Common throughout the county. It breeds on Llangorse Lake, and occasionally on smaller lakes and ponds here, 
but in sparse numbers. It may be often seen on any large pool in the Usk, or Wye, diving incessantly. I have never noticed it on the deep bogs of the county, nor on any of the hill-streams.

GUILIEMO'T, Uria troile.

I can record the occurrence of one specimen, which was picked up dead after a storm in the neighbourhood of Llanwrtyd, in this county.

\section{CORMORANT, Graculus carbo.}

I think visited us formerly oftener than is generally supposed, probably following the course of the river from the sea in search of Trout. I have seen one on Newton Pool, near Brecon, but not of late years. Two or three have been killed at Glanusk, on the Usk, the seat of Lord Glanusk. Mr. Alfred Crawshay has observed it at Llangorse several times, I have seen it killed on the Usk near this house, and other specimens have been obtained in this county. It has, however, somewhat decreased here, and is now seldom seen. On the 26th of July, in the Jubilee year, 
I887, I paid a visit to Craig-y-Deryn, the Bird Rock, near Towyn, one of the principal breeding places of the Cormorant in Wales. This rock stands boldly out, a most conspicuous object on the left-hand side of the valley looking down towards Towyn, and is precipitous on the two sides jutting out into the valley; but its top may be reached by walking over the hill from the valley behind it. These two sides, like a miniature Gibraltar, are nearly perpendicular, and it is on the ledges of the side facing towards Cader Idris that the Cormorant builds and rears its young in safety. The guide-books do not give the height of the rock, but I should say it would be about $400 \mathrm{ft}$., more or less.* I know the Cormorants looked very small from where we stood. A road skirts the bottom, and the nests, with the young, for the most part about three-parts grown, were easily distinguishable from the quantity of white

* A friend of mine has since, by means of an aneroid barometer, determined the highest point to be 650 feet, and the precipitous sides about 550 feet. 
I3O THE BIRDS OF BRECONSHIRE.

droppings that fall beneath the nests and stain the surface of the rock.

We watched the old birds, particularly the hens, feeding their young, and the flight of the parent birds as they circled and soared round the face of the rock, and particularly the flight of the large dark cock birds was grand in the extreme. The young, during the time they were being fed, made a continual querulous crying. Every now and then a Sparrowhawk would sweep round the face of the rock; instantly the old cock Cormorants would trumpet out their hoarse note of alarm and defiance, to be answered, in their turn, by the cries of the hens and young, making a babel of noise that must be heard to be understood. These sounds would ultimately die away, and perfect silence would reign until the appearance of another hawk would start afresh the trumpeting, and set the echoes replying. It was impossible for me to count the nests from where I was on the road, but at a rough guess I should say there were about thirty there then, but whether any young had flown I am unable to say. 
The fishermen say that there are Cormorants on the rock blind from age, and that they never leave the rock, but are fed by the younger birds; but I am assured by a naturalist, living at Aberystwith, who knows the rock well, that he has many times seen it without a single Cormorant on it. They also say that the younger birds conduct the blind old birds to the sea, which I think is more likely to be true.

At the foot of the rock were two dead birds that seemed to have been shot when away, and to have flown home to die. There were also several small rabbits feeding directly under the rock, of which the Cormorants seemed to take no notice. The nests, as far as I could see, never seemed to contain more than three birds, and these must be able to fly well before they could get from the rock to reach the sea, distant about four miles. I watched the busy scene for more than an hour, and left about half-past six, when fresh arrivals kept coming in from the sea in little strings of four, five, and six.

I may add that of course it does 
I32 THE BIRDS OF BRECONSHIRE.

not breed in this county. Williams gives the Welsh name of Cormorant as Morfran, or Sea Crow.

THE SHAG, Graculus cristatus.

I have only known of one occurrence of this bird in the county and that was killed by Mr. Williams-Vaughan's keeper on the Wye, near Erwood, a few years since; it was a young bird but in very fine plumage. Its appearance so far inland can only be regarded as accidental as it is essentially a sea bird.

\section{GANNET, Sula bassana.}

Miss Lloyd tells me that at Nantgwylt, some years ago, she picked up a fine Gannet alive (evidently blown in by a storm), and kept it alive for some little time by feeding it with fish and periwinkles. The nearest sea-coast must be at least thirty miles from where the bird was found, and shows the fearful power of the storms that occasionally occur on our iron-bound coasts. About 20 years ago a man passing by Cefn Park, near Brecon, seeing a large white bird in a 
THE BIRDS OF BRECONSHIRE. I33

wood there, fired and killed it; he brought it to the late Mr. Williams, of Closceddau, who had it preserved. On inspecting it I found it to be a Gannet, an old bird, in most beautiful plumage, and it had evidently arrived at its strange resting place in the same manner as the first-named specimen. I must not omit to mention that Cefn Park is certainly thirty miles from the sea, as the crow flies. Another one, an immature bird, was killed at Llangorse Lake by the late Capt. Crawshay Ralston, of Pontywall, but as this bird does not attain its adult white plumage for some few years, I should imagine it was in its second year.

COMMON TERN, Sterna fuviatilis.

May often be seen at Llangorse, skimming over the expanse of the lake with its peculiarly easy and graceful flight. Mr. D. Gwynne Vaughan shot a solitary bird of this species on the summit of the Eppynt Hills. It has also been obtained on the Wye and Usk, but is, I regret to say, only an occasional summer visitant with us. Williams gives the Welsh for Sea Swallow which is another name for 
134 THE BIRDS OF BRECONSHIRE.

the common Tern, gwenol y mor neu yscracan, the Sea Swallow or Scray, or Morwennol.

BLACK TERN, Sterna fissipes.

Two specimens of the Black Tern were shot on Llangorse Lake by Mr. C. J. P. Nash, in the year I889, and were preserved. I take this information from the valuable transactions of the Woolhope Naturalist's Field Club.

LESSER TERN, Sterna minuta.

Capt. Swainson writes me that he has observed this bird on Llangorse Lake two or three times. He is well acquainted with it, having often seen it near Towyn, and has, therefore, no doubt of its occurrence here.

\section{BLACK HEADED GULL,}

\section{Larus ridibundus.}

The only occurrence that I have known of this elegant little Gull was picked up dead on the Usk near this house in the early part of last year. It was in winter plumage. The black, or 
THE BIRDS OF BRECONSHIRE. I35

rather brown, on the head of this gull only occurs in summer. It has no doubt occurred here before, but has been unrecorded.

KITTIWAKE, Larus tridactylus.

This Gull has been killed on Llangorse Lake; it is, however, seldom seen here. Mr. Crawshay has killed it on the Usk, another was killed at the Waterworks, Brecon, in 1885. I also observed a bird evidently in bad health on the river near here in I896, which was a young Kittiwake (immature), and which I have now preserved. Another was picked up dead at Llanfillo four years ago, and is now stuffed at Tregunter; but the same remark will apply to this bird as to the preceeding one.

\section{COMMON GULL, Larus canus.}

Not uncommon in the county, especially after a stress of weather. I have observed it on the Wye, near Builth, at Llanwrtyd, occasionally also on the Usk, and it may often be seen at Llangorse. It takes good care of itself when inland, being fully alive to the fact that its large 
breadth of wing and snowy plumage renders it most conspicuous. I often see the Gulls flying up the Usk past my window and sometimes settling on the Rock Pool. Their presence generally denotes stormy weather at sea, although I must be fully 35 miles from the nearest sea coast. Williams gives the Welsh for Gull as Groylan or Wylan and quotes:-

" $E$ wnaeth y frân ei whyth fry A'r wylan ar ei wely."

Sion Dafydd.

HERRING GULI, Larus argentatus.

I have seen it here but very seldom. I remember fishing in the Wye, at Erwood, late one beautiful summer evening, when a very large Herring Gull flew slowly up the river and passed close over my head. When exactly above me he turned his head on one side, without deviating in the least from his course, gave me a look, as much as to say, "Only a harmless brother angler," and passed on his way without the slightest apparent concern. Welsh, Groylan ysgadan.

LESSER BLACK BACKED GULL. Larus fuscus.

This bird occurs regularly every spring 
following the courses of the Wye and the Usk. It also occurs at other times but not frequently. In the month of July, 1897, I killed a very fine bird under my house for the purpose of identification. Some books give the Welsh Groylan fechan cefnddu, but this is the literal translation.

\section{MANX SHEARWATER,}

\section{Puffinus anglorum.}

One of these birds was picked up dead close to the borders of the county, near Llanwrtyd. It was fortunately preserved, and I have often inspected it. Of course it was only borne there "on the wings of the wind."

\section{THE SOOTY SHEARWATER, Puffinus griseus.}

Through the kindness of Col. Wood I have to record the occurrence of one of these birds that had been killed on the Wye, near Gwernyfed, a few years since. He sent me the bird to Wiltshire, where I was staying, and I took it to Bath to be stuffed. Unfortunately when I went for it the man had left, so I lost the 
I38 THE BIRDS OF BRECONSHIRE.

bird. I have no doubt, however, of its identity.

STORM PETREL, Procellaria pelagica.

One of these homeless little wanderers was picked up dead on the Wye, at Clyro, near Hay, some years since; and another was found dead on the "Captain's Walks," one of the most favourite promenades of our town. This bird of the Ocean is supposed to be called "The Petrel" after St. Peter, from its habit of flitting just over the surface of the sea, appearing to be almost walking on the waves. It has always been considered a bird of ill omen by sailors, as its appearance invariably presages a storm. It is called by them "Mother Carey's Chicken." Some give the Welsh as Cas gan longwr.

\section{THE FORK TAILED PETREL, Procellaria leachii.}

A specimen of this bird, sometimes called Leach's Petrel, was shot on the banks of the River Wye, Breconshire, by Col. Wood's keeper, near Gwernyfed, on 
THE BIRDS OF BRECONSHIRE. I39

Monday, October I5th, I877. The previous night and morning were remarkable for one of the severest south-westerly gales this country had experienced for many years. Another was picked up on 24th November, 1892, near Trecastle, and was warm when brought to me. It was in excellent plumage but seemed to have perished from exhaustion. To the best of my recollection it had been stormy the previous day; it is now in Mr. A. Crawshay's collection. A third was picked up at the Skreen, Errwood, on the borders of the county, by Mr. WilliamsVaughan, after one of the violent storms of I88I.

He that hath found some fledg'd bird's nest, may know At first sight, if the bird be flown;

But what fair well or grove he sings in now

That is to him unknown.

Henky VıUGHaN, Silurist, 1650. 


\section{SUMMARY.}

Order I. RAPTORES.

Fam. FALCONIDAE.

Aquila chrysaëtus, Linn.

Pandion haliæëtus, Linn.

Buteo vulgaris, Leach.

Pernis apivorus, Linn.

Milvus regalis, Bris.

Falco candicans, Gmel.

" peregrinus, Gmel.

" subbuteo, Linn.

", æsalon, Gmel.

, tinnunculus, Linn.

Circus æruginosus, Linn.

, cyaneus, Linn.

Accipiter nisus, Linn.

Fam. STRIGIDAl.

Otus vulgaris, Flem.

" brachyotus, Forst.

Syrnium aluco, Linn.

Strix flammea, Linn.

Order II. INSESSORES.

Fam. LANIDA

Lanius excubitor, Linn. 
Lanius collurio, Linn.

Fam. TURDID承.

Turdus viscivorus, Linn.

" musicus, Linn.

" merula, Linn.

" pilaris, Linn.

" iliacus, Linn.

" torquatus, Linn.

Fam. CinClides.

Cinclus aquaticus, Bechst.

Fam. ORIOLID As.

Oriolus galbula, Linn.

Fam. Muscicapidat.

Muscicapa grisola, Linn.

" atricapilla, Linn.

Fam. CoRvid瓜.

Corvus corax, Linn.

" corone, Linn.

" cornix, Linn.

" frugilegus, Linn.

Pyrrhocorax graculus, Linn.

Corvus monedula, Linn.

Garrulus glandarius, Linn.

Pica caudata, Flem.

Nucifraga caryocatactes, Linn. 
Fam. STURNIDAF.

Sturnus vulgaris, Linn.

Pastor roseus, Linn.

Fam. SyLviID瓜.

Accentor modularis, Liun.

Erythaca rubecula, Linn.

Ruticilla phœnicura, Linn.

, tithys, Scop.

Saxicola œnanthe, Linn.

" rubicola, Linn.

" rubetra, Linn.

Salicaria phragmitis, Bechst.

" strepera, Vieill.

, locustella, Lath.

Philomela luscinia, Linn.

Sylvia atricapilla, Linn.

" hortensis, Gmel.

" cinerea, Lath.

" sylviella, Lath.

Phylloscopus sibilatrix, Bechst.

, trochilus, Linn.

" rufa, Bechst.

Regulus cristatus, Koch.

, ignicapillus, Brehm.

Fam. TrogrodyTIDA.

Troglodytes parvulus, Koch. 
Fam. PARID瓜。

Parus major, Linn.

cæruleus, Linn.

" ater, Linn.

". palustris, Linn.

" caudatus, Linn.

Fam. MoTACILIID五.

Motacilla yarrelli, Gould. sulphurea, Bechst. rayi, Bonap. flava, Linn.

FAM. ANTHID AH.

Anthus pratensis, Linn.

" arboreus, Bechst.

Fam. ALAUDID瓜.

Alauda arvensis, Linn.

" arborea, Linn.

Fam. AMPELID Á.

Ampelis garrulus, Linn.

Fam. Certhimder.

Certhia familiaris, Linn.

Fam. SirTid瓜。

Sitta cæsia, Meyer. 
Fam. EMBERIZIDAE.

Emberiza nivalis, Linn.

, miliaria, Linn.

, schœniclus, Linn.

, citrinella, $\operatorname{Lin} n$.

, cirlus, Linn.

Fam. Fringirimat.

Fringilla colebs, Iinn.

, montifringilla, Linn.

, carduelis, Linn.

, $\quad$ spinus, $\operatorname{Linn}$.

Linota cannabina, Linn.

, flavirostris, Linn.

, linaria, Linn.

, rufescens, Vieill.

Passer montanus, Linn.

, domesticus, Linn.

Coccothraustes chloris, Linn.

, vulgaris, Steph

Pyrrhula vulgaris, Temm.

Fam. Loxim

Loxia curvirostra, Linn.

, pityopsittacus, Bechst.

Fam. PICID死.

Picus viridis, Linn.

, major, Linn.

, minor, Linn. 
Picus martius, Linn.

Jynx torquilla, Linn.

Fam. UPUPIDA.

Upupa epops, Linn.

Fam. CUCUlid

Cuculus canorus, Linn.

Fam. AlCEDINID瓜。

Alcedo ispida, Linn.

Fam. HIRUNDINIDAE.

Hirundo rustica, Linn.

" urbica, Linn.

", riparia, Linn.

Fam. CYPSELIDAF。

Cypselus apus, Linn.

Fam. CAPRIMUlgid As.

Caprimulgus europæus, Linn.

Order III. RASORES.

Fam. Columbidas.

Columba palumbus, Linn.

œnas, Linn.

livia, Temm.

Turtur auritus, Gray. 


\section{Fam. Phasianid 死.}

Phasianus colchicus, Linn.

Fam. TETRAONIDAE.

Tetrao tetrix, Linn.

". scoticus, Lath.

Perdix cinerea, Lath.

"rufa, Lath.

Coturnix vulgaris, Flem.

\section{Order IV. GRALLATORES.}

Fam. CHARADRIID瓜.

Glareola pratincola, Linn.

CEdicnemus crepitans, Temm.

Charadrius pluvialis, Linn.

Vanellus cristatus, Meyer.

Eudromias morinellus, Linn.

Egialitis hiaticula, Linn.

Strepsilas interpres, Linn.

Fam. SCOLOPACIDA.

Totanus glottis, Pall.

" calidris, Linn.

" ochropus, Linn.

Tringoides hypoleucus, Linn.

Tringa canutus, Linn.

" subarquata, Güld. 
Tringa maritima, Brün.

" alpina, Linn.

Phalaropus fulicarius, Linn.

Scolopax rusticola, Linn.

Gallinago major, Gmel.

" media, Leach.

" gallinula, Linn.

Numenius arquatus, Linn.

Fam. GRUID As.

Grus cinerea, Bechst.

Fam. ARDEIDAA.

Ardea cinerea, Linn.

, purpurea, Linn.

" comata, Pall.

Botaurus stellaris, Linn.

" minutus, Linn.

Fam. RALLID瓜.

Rallus aquaticus, Linn.

Crex pratensis, Bechst.

" porzana, Linn.

Gallinula chloropus, Linn.

Fulica atra, Linn.

Order V. NATATORES.

Fam. ANATID正.

Cygnus musicus, Bechst. 
Anser ferus, Gmel.

" segetum. Gmel.

", albifrons, Gmel.

", leucopsis, Bechst.

" brachyrhynchus, Baill.

" bernicla, Linn.

" canadensis, Linn.

Tadorna vulpanser, Flem.

Anas boschas, Linn.

" strepera, Linn.

,, clypeata, Linn.

, acuta, Linn.

" penelope, Linn.

Querquedula crecca, Linn.

, circia, Linn.

Fuligula ferina, Linn.

$$
\begin{aligned}
& \text { " marila, Linn } \\
& \text { cristata, Leach. }
\end{aligned}
$$

Clangula glaucion, Linn.

Harelda glacialis, Linn.

Ėdemia nigra, Linn.

Mergus albellus, Linn.

" serrator, Linn.

„ merganser, Linn.

Fam. Colymbid无.

Colymbus glacialis, Linn.

, arcticus, Linn.

" septentrionalis, Linn. 
Fam. PoDICIPID瓜.

Podiceps cristatus, Linn.

" minor, Gmel.

Fam. ALCID 瓜.

Uria troile, Linn.

Fam. Pelecanid

Graculus carbo, Linn. cristatus, Faber.

Sula bassana, Linn.

Fam. LARID无.

Sterna fluviatilis, Naum.

" fissipes, Linn.

" minuta, Linn.

Larus tridactylus, Linn.

" ridibundus, Linn.

" canus, Linn.

„, argentatus, Gmel.

„ fuscus, Linn.

Fam. PROCELIARID㤰.

Puffinus anglorum, Temm.

" griseus, Gmel.

Procellaria pelagica, Linn.

" leachii, Temm. 



\section{A D DENDA.}

A friend of mine has kindly informed me that a Nightingale was heard singing this year at Crickadarn, and as my informant knew its song well, I think it is worth while recording the fact, as this bird is certainly uncommon in that part of the county. It seems, however, to visit us more often than formerly.

As one of the latest and most useful of the Natural Histories of the British Isles contains the statement that the Hawfinch never breeds in Wales, I have taken great pains to ascertain as far as possible, every place in the county where they are known to have bred, and I have to thank Mr. H. Harries, of Brecon, for kindly supplying me with the following additional particulars :-

A nest was found at Llangattock, Crickhowell, in. I894, with four eggs. Three birds were hatched, and two were 
reared and kept in an aviary at Llangattock by Mr. Harries's uncle, but they were unfortunately destroyed by rats.

In 1893 a hen Hawfinch was caught in a net in the garden at Llangattock and kept in an aviary there for three years. Its food was hemp and canary seed. Since then Hawfinches have often been seen in the district and their nests found. From the above it will be seen that there can be no possible doubt of its breeding in this county, and it seems to favour the southern part of the county from Buckland down to Crickhowell more than other parts, although it will be remembered that I saw a young bird unable to fly that had been caught near Brecon. (See page 6o).

\section{NIGHTJAR, Caprimulgus europoens.}

I should have added in my notice of this bird, that one evening I watched a Nightjar skimming over the surface of the Rock Pool, on the Usk, under my house, and drinking repeatedly, after the manner of the Swallows. 
I have thought it better to add this note, as its habit of drinking whilst on the wing, may possibly be new to many naturalists.

\section{GUILIEMOT, Uria troile.}

The local name for this bird at the various places where it occurs on the South Wales Coast, is "Elligug" or "Helligog." Mr. Thos. Henry Thomas of the Cardiff Naturalists' Society says that this name is Welsh; "Heli" meaning salt, or saltwater, and "Gog" cuckoo. I have to thank him for this note, which occurs in his interesting paper entitled "A visit to the Gannet Settlement upon the Island of Grassholm," which he kindly sent me. 



\section{N D E X.}

Bittern, 100

Blackbird, 25

Little, 102

Blackcap, 44

Black Grouse, 77

Brambling, 56

Bullfinch, 60

Bunting Cirl, 54

" Common, 53

" Reed, 53

" Snow, 53

Buzzard, 6 Yellow, 54

" Honey, 8

Chaffinch, 55

Chiffchaff, 45

Chough, 36

Coot, 109

Cormorant, 128

Crake, Corn, 103

Green, 132

, Spotted, 104

Crane, Common, 97

Creeper, Tree, 52

Crossbill, 61

" Parrot, 62

Crow, Carrion, 33

" Hooded, 34

Cückoo, 66

Curlew, 95

$" \quad$ Stone, 85

Dipper, 28
Diver, Black-throated, 126

" Great Northern, 125

" Red-throated, 126

Dotterel, 87

Dove, Ring, 72

" Rock, 74

" Stock, 73

" Turtle, 74

Duck, Gadwall, 117

" Garganey, 120

" Golden-eye, 122

, Long Tailed, 122

, Scoter, Common 123

" Pintail, 118

" Pochard, 120

"Scaup, I20

, Shoveller, 118

" Teal, 119

" Tufted, 121

"Wigeon, 118

, Wild, 116

Dunlin, 91

Eagle, Golden, 3

Falcon, Greenland, 13

Falcon, Peregrine, 13

Fieldfare, 26

Finch, Bramble, 56

Bull, 60

" Gold, 56

" Green, 59

" Haw, 59

Fire-crested Wren, 47 
Flycatcher, Pied, 30

Furzechat, 42

Gannet, 132

Gadwall, 117

Garganey, 120

Golden-crested Wren, 46

Golden Oriole, 29

Goldeneye, 122

Goldfinch, 56

Goosander, 124

Goose, Bean, 111

" White-fronted, 113

" Bernicle, 114

" Pink Footed, 114

" Brent, 114

" Canada, 115

, Greylag, 111

Grebe, Great Crested, 126

Little, 127

Greenfinch, 59

Greenshank, 88

Grouse, Black, 77

Guill Red, 78

Gall, Black-headed, 134

" Lesser Black-backed,

"Common, 135

" Herring, 136

" Kittiwake, 135

Harrier, Hen, 17

Hawfinch, 59

$$
\text { Marsh, } 17
$$

Hedgesparrow, 40

Heron, 97

" Purple, 100

, Squacco, 100

Hobby, 16

Hoopoe, 65
Hybrid Pheasant and

Black Game, 83

Jackdaw, 36

Jack Snipe, 95

Jay, 37

Kestrel, 18

Kingfisher, 66

Kite, 9

Knot, 91

Landrail, 103

Lapwing, 86

Lark, Sky, 51

"Wood, 52

Linnet, 57

Magpie, 37

Martin, 67

" Sand, 67

Merganser, Red-breasted,

Merlin, 18

Missel Thrush, 24

Moorhen, 108

Nightingale, 43

Nightjar, 68

Nutcracker, 38

Nuthatch, 53

Osprey, 6

Ouzel, Ring, 27

"Water, 28

Owl, Barn, 22

" Brown. 21

" Long-eared, 21

" Short-eared, 21 
Partridge, Grey, 79

Pastor, Rose-coloured, 40

Peregrine, 13

Petrel, Storm, 138

" Forked-tailed, 138

Phalarope, Grey, 92

Pheasant, 74

Pintail, 118

Pipit, Meadow, 51

, Tree, 51

Plover, Golden, 86

, Green, 86

, Ringed, 87

Pochard, 120

Pratincole, Collared, 85

Quail, 82

Rail, Water, 102

Raven, 31

Red-backed Shrike, 24

Red Grouse, 78

Redpole, Lesser, 58

Redshank, 88 INealey, 57

Redstart, 41

Redwing, 27

Black, 41

Reed Warbler, 42

Ring Ouzel, 27

Robin, 40

Rock Dove, 74

Rook, 35

Sandpiper, Green, 89

" Curlew, 90

" Purple, 90

Scaup, 120

Common, 90

Shag, 132

Shearwater, Manx, 137
Shearwater, Sooty,137

Sheldrake, 115

Shoveller, 118

Shrike, Great Grey, 24

Siskin, 57 Red-backed, 24

Sky Lark, 51

Smew, 123

Snipe, Common, 94

" G:eat, 92

" Jack, 95

Sparrow, Hedge, 40

, House, 59

" Tree, 58

Sparrowhawk, 19

Starling, 38

Stock Dove, 73

Stone Curlew, 85

Stonechat, 42

Storm Petrel, 138

Swallow, 67

Swan, Wild, 110

Swift, 67

Teal, 119

Tern, Black, 134

" Common, 133

" Lesser, 134

Thrush, Missel, 24

", Song, 25

Titmouse, Blue, 49

" Cole, 49

, Great, 48

," Long-tailed, 49

,. Marsh, 49

Tree Creeper, 52

Turnstone, 87

Turtle Dove, 74

Twite, 57

Wagtail, Blue-headed, 50

" Grey, 50

" Pied, 50 
Wagtail, Yellow, 50

Warbler, Blackcap, 44

, Garden, 44

" Grasshopper, 44

" Reed, 42

" Sedge, 42

" Willow, 45

" Wood, 45

Water Ouzel, 28

Rail, 102

Waxwing, 52

Wheatear, 42

Whimbrel, 96

Whitethroat, 45

Wigeon, 118

Lesser, 45

Woodcock, 92
Wood Lark, 52

Woodpecker, Green, 62 Greater Spotted, 62 " Lesser Spotted,

Wood" Pigeon, 72 Great Black, 64

Wren, Common, 48

" Gold-crested, 46

" Fire-crested, 47

"Willow, 45

"Wood, 45

Wryneck, 65

Yellowhammer, 54 
LIST OF

S UBSCRIBERS 



\section{LIST OF SUBSCRIBERS.}

Rhys P. Allaway, Esq., Aberartro, Llanbedr,
Merionethshire

Chas. F. Archiball, Esq., Headingley

O. V. Alpin, Esq., F.L..S., Bloxham

Mr. Edmund Adney, Ashgrove, Brecon

J. Arthur Acton, Eisq., Wrexham.

Herbert E. Bradley, Esq., Cefuparc, Brecon

J. Willis Bund, Esq., F.L.S., I5, Old square, Lincoln's Inn, London

E. F. Lynce Blosse, Esq., Peterstone Super Ely, Cardiff

Rev. William Bowen, Vicarage, Llangorse

Rev. John Bowen, The Vicarage, Talgarth

W. C. J. Ruskin Butterfield, Eisq., St. Leonardson-Sea

Brecon Literary Institution ( $\mathrm{Mr}$ Hadley Watkins, Secretary and Librarian).

J. A. Harvie Brown, Esq., J.P., Dunipace House, N.B.

F. L. Blathwayt, Eisq., B.A. Weston-Super-Mare

Rev. A. Browne, Trebinshun, Bwlch

Arthur Beckwith, Esq., J.P., The Grove, Crickhowell

Ivor Bowen, Esq., Barister-at-Law, South Wales Circuit

M. H. Cazalet, Esq., Aberyskir, Brecon

S. H. Cowper-Coles, Esq., Penmyarth, Crickhowell, (2 Copies) Cardiff Free Library (John Ballinger, Essq.,

Mrs. Crichton, Wye Cliff, Hay, R.S.O.

Miss Cadmore, Dolangoch, Brecon

James Cockcroft, Esq., City Librar an, Public Library and Museum, Hereford (2 Copies) 


\section{LIST OF SUBSCRIBERS.}

Herbert Crawshay, Esq., Stormer Hall, Leintwardine, R.S.O., Herefordshire

Edward Caddick, Essq., Edgbaston

Dr. A. J. H. Crespi, Wimborne

E. W. Colt, Esq., M.A., Streethay

Mr. Thomas Carver, The Old Book Store, Hereford

R. D. Cleasby, Essq., J.P., Penoyre, Brecon (2 copies)

Mr. Cross, Head Keeper, Buckland, Brecon

Hon. Robt. C. Devereux, J.P., D.L., Glyncelyn, Brecon

Mr. Evan Davies, Police Sergeant, Sennybridge J. A. Doyle, Essq., Penydarren, Crickhowell

Charles Morgan Davies, Esq., Architect, Merthyr Tydfil

Morgan W. Davies, A.M.I.C.E., Civil and Mining Engineer, Swansea

Miss Downes, Castle street, Brecon

E,dwyn Blissett Davies, Brecon

Mr. Howel Davies, Pannau, Brecon

W. Henry Dobie, Esq., M.B., Chester

J. H. Davies, Esq., Lincoln's Inn, London

Mr. Henry Davies, The Watton, Brecon

W. Herbert Evans, Esq., Barrister-at-Law, Brecon

Mr. John Evans, Ivy Tower, Crickhowell

Miss Logan Elmslie, St. Austin's, Farnham, Surrey

Mr. Edward T. Edwards, The Struet, Brecon

W. Warde Fowler, Esq., M.A., Oxford

The Right Hon. Lord Glanusk, Glanusk Park, Crickhowell

Miss Games, The Struet, Brecon

Howel Gwynne, Esq., Llanelwedd Hall, Builth J. Eglinton A. Gwynne, Essq., J.P., F.S.A., \&c., Folkington Manor

J. H. Gurney, Eisq., Keswick Hall, Norwich 


\section{LIST OF SUBSCRIBERS.}

William Griffiths, Esq., J.P., Pencaemawr, Merthyr

Alfred Gwynne-Vaughan, Esq., The Strand, Builth

Edmund Gwynne, Essq.,Llanthetty, Breconshire

Robert T. Griffiths, Eisq., solicitor, Hay

General Glyn, C.B., Chequers Mortimer, Berks,

Colonel R. D. Gough, Yniscedwyn, Swansea Valley

W. H. Gimson, Esq., Manager Birmingham Bank, Brecon.

Aneurin George, Esq., ex-Mayor of Brecon, Mount Street

Viscountess Hereford, Tregoyd, Breconshire

C. Hartley, Esq., Royal College, Columba

Dr. W. Howells, Talgarth

W. J. Harding, Esq., M.A., Alleyne's Grammar School, Stone, Staffs.

W. Harpur, Esq., M.Inst.C.E., F.S.I., \&c., I97, Severn Road, Cardiff, and Lake View, Llangorse.

H. F. W. Harries, Esq., Solicitor, Brecon

H. Scott Hall, Esq., Dormington Court

G. H. Caton Haigh, Esq., Penrhyndeudraeth

R. S. Hodgson, Esq., J.P., Yniscedwyn (2 copies)

J. Gwynne Holford, Esq., J.P., Buckland, Bwlch

John Hotchkis, Esq., J.P., D.L., Pontarfran, Brecon

Mr. Richard Hargest, Brecon.

Herbert James, Esq., Barrister-at-Law, Vaynor Cottage, Vaynor (6 Copies)

Edmund J. J. Jones, Esq., Fforest Legions, Pont-nedd-fechan, Glyn-neath

Gwillym C. James, Esq., J.P., Merthyr Tydfil (2 Copies)

Edward Jones, Esq., J.P., D.L., Snatchwood House, Pontypool (2 Copies)

H. Jones-Williams, Esq., J.P., Cui Parc, Talybont-on-Usk 


\section{IIST OF SUBSCRIBERS.}

Capt. Fullarton James, Barrister-at-Law, Chief Constable of Radnorshire, Penybont

Evan Jones, Esq., J.P., Tymawr, Aberdare

M. Powell Jones, Esq., Pwll Court, Llangynidr

William Jones, Esq., Oaklands, Llangynidr

Lewis W. H. Jones, Esq., Solicitor, Llyswen

Ivor James, Esq., Registrar University College of Wales, Brecon

Mr. Thomas Jones, Bookseller and Stationer, Brecon (6 Copies)

David Jones, Esq., Pontypool

D. T. Jeffreys, Esq., Greenfield, Brecon

Col. Justice, Newport, Mon.

Dr. W. R. Jones, Sennybridge, Brecon

Brychan Jeffreys, Esq., Trecastle

Rev. J. Bowen Jones, B.A., The Watton, Brecon

Rev. H. J. Church Jones, 13 The Struet, Brecon

Sir John Dilwyn Llewelyn, Bart M.P., Penllergare, Swansea

Miss Lewis Lloyd, Llandefaelog, Brecon

John Lloyd, Essq., J.P., Barrister-at-Law, London

Major General H. H. Lee, The Mount, Dinas Powis

Henry Laugton, Esq., MI.R.C.S., Brighton

Mr. J. W. Lloyd, Kington

Percy Laybourne, Eisq., Greenmeadow, Caerleon

A. G. Lundie, Esq., 34, Oakfield street, Cardiff

D. Hughes-Morgan, Esq., High Sheriff of Breconshire, Bedford Court Mansions, Bedford square, London

The Misses Philip Morgan, Buckingham Place, Brecon

Mrs. Morgan, Watton House, Brecon (2 Copies) Edward Pritchard Martin, Esq., J.P., Dowlais, (2 Copies)

Percy Morton, Esq., M.A., Bridge street, Brecon John Story Masterman, Essq., 55, Campden. House Road, London, W.

C. Berkeley Margetts, Esq., Gazeley House, Huntingdon 


\section{IIST OF SUBSCRIBERS.}

Mr. Herbert W. Marsden, 40 Triangle, W, Clifton, Bristol (20 Copies)

Herbert H. Maybery, Esq., The Priory, Brecon Chas. Morley, Eisq., M.P. for Breconshire, 46, Bryanstone Square, London

Walter J. Morgan, Esq., J.P., Brynheulog, Hirwain

Henry Wm. Martin, Esq., Dowlais

James Morgan, Esq., J.P., Lloyds Bank, Brecon

Col. John Morgan, V.D., J.P., D.I., Bank House, Brecon

Capt. Stuart Morgan, Bolgoed, Brecon

Joseph E. Moore, Esq., J.P., Dyffryn, Neath

B. St. J. Attwood Mathews, Eisq., Pontrilas

Herbert Massey, Esq., F.E.S., Burnage, Didsbury

A. Holt Macpherson, Esq., F.Z.S., 5I, Gloucester Terrace, W.

H. J. Mannings, Esq., I56 Gresham House, O1d Broad Street, London

w. Clifton Mogg, Esq., Brynwern Hall, Newbridge-on-Wye

Mrs O. Vaughan Morgan, I3 The Boltons, South Kensington, London.

Penry Vaughan Morgan, Essq., I3 The Boltons, South Kensington, London.

Aveline Maybery, Esq., The Priory, Brecon.

Edward Vaughan Morgan, Esq., 32, Harrington Gardens, London (4 copies)

Septimus Vaughau Morgan, 37, Harrington Gardens, London, S.W. (2 copies)

A1derman Vaughan Morgan, Treasurer Christ's Hospita1, London

Mr W. Martin, Assistant Overseer, Parish of St. David's, Brecon

Capt. T. L. Morgan, R.A., J.P., Oakfield, Hay

W. S. Miller, Esq., J.P., Forest Lodge, Brecon

Arthur Mohun Harris, Esq., Llandefalle, Talgarth

Mr. A. J. Morris, Is High Town, Hay

Digby S. Nicho1, Esq., F.L.S., F.Z.S., J.P., Usk Francis Nicholson, E.sq., F.L.S., Manchester Walter North, Esq., Stipendiary of Merthyr Tydfil, Brecon 


\section{LIST OF SUBSCRIBERS.}

Professor Newton, F.R.S., F.I.S., F.Z.S., Magdalene College, Cambridge.

Count Prof. E. Arrigoni Degli Oddi, Padua Rev. T. M. Bulkeley Owen, Tedsmore Hall Evan Owen, Esq., Builth.

Dr. T. Parker Powell, Lincoln

Mrs. Powell Powel, Castle Madoc, Brecon

D. Price Powell, Esq., J.P., Howey Hall, Llandrindod

John Price, Essq,. Solicitor, Brecon

H. Penry Powel, Esq., 26, First Avenue, Brighton

I. Ralph Price, Esq., Claverham House, near Yatton, Somersetshire

Thomas Parkin, Esq., M.A., F.R.G.S., High Wickham

Col. A. N. Phillips, Bronllys Castle, Talgarth

J. Vaughan Phillips, Esq., 30 Tavistock Crescent, Westbourne Park, London.

Capt. G. H. Pering, Peterstone Court, Brecon

Mr Vaughan Powel1, Sennybridge

Rev. L. Pryce, 95, The Struet, Brecon

Rees Powe11, Essq., J.P., Ysclydach, Sennybridge

Owen Price, Esq., J.P., Nantyrharn, Cray

Mr David Price, The Bulwark, Brecon

H. Ashley Phillips, Esq., The Palace, Chippenham, Wilts.

Cleveland Vaughan Phillips, Esq., Bengal, India

Mr. T. W. Price, I8 Bridge street, Brecon

Howe1, J. J. Price, Eisq., B.A., J.P., Barristerat-Law, Greensted Hall, near Ongar

Hon. W. Rothschild, M.P., Tring

A. C. Rogers, Esq., Red Lodge, Basset, Southampton

Mr. D. M. Richards, Aberdare

D. P. Roberts, Esq., I20, Croydon, Surrey

Mrs Reed, 7, Onslow square, London

Miss Rice, 52, Cadogan Square, London, W 


\section{IIST OF SUBSCRIBERS.}

Rev. D. A. Rowlands, B.A., Glyncoed, Cardigan

Rev. T. C. Richards, Brynderwen, Llanfihangeltalyllyn

D. Valentine Rees, Essq., J.P., Lion street, Brecon

Major Roche, Tregunter, Talgarth (2 copies)

Capt. E. A. Swainson, Woodlands, Brecon

Capt. R. Sandeman, J.P., Danypark, Crickhowell

R. Stratton, Esq., The Duffryn, Newport

Harmer Steele, Esq., 52 Gillingham street, London, S.W.

Rev. F. S. Stooke-Vaughan, Wellington Heath Vicarage, Ledbury.

Mrs. Samuelson, Hyde Park Gardens, London, W.

The Right Hon. Lord Tredegar, Tredegar Park, Newport

H. E,dgar Thomas, Esq., Sunny Bank, Brecon (3 copies)

Molyneux F. Thomas, Esq., Solicitor, Brecon

Morgan Thomas, Esq., J.P., Abersenny, Brecon Frank Travers, Esq., Cathedine Hill, Bwlch, Breconshire

Col. W. Jones Thomas, J.P., Llanthomas, Hay John Morgan Thomas, Esq., J.P., Glyngarth, Brecon

Commander A. Evan Thomas, Caerwnon, Builth W. Lilewelyn Thomas, Esq., Ely Cottage, Brecon

C. Venables-Llewelyn, Esq., J.P., Llysdinam, Newbridge-on-Wye (2 Copies)

John Vaughan, Eisq., Solicitor, Merthyr Tydfil

H. Vaughan Vaughan, Esq., The Castle, Builth

J. Edwards Vaughan, Esq., J.P., Rheola, Neath

Sir John Williams, Bart., London, W.

His Honour Judge Gwilym Williams, Miskin Manor, Glamorganshire 
Rev. C. C. Wood, Glanhonddu, Brecon

Woolhope Naturalist's Field Club, Hereford (per H. Cecil Moore, Esq., 26, Broad Street, Hereford)

Rev. Preb. Garnons Williams, Abercamlais, Brecon

Mr. T. Hadley Watkins, L.T.S.C., Brecon

J. J. Williams, Esq., J.P., Aberclydach House, Talybont-on-Usk

Rees Williams, Esq., J.P., County Club, Brecon Miss E. A. Williams, Penpont, Brecon

Major R. D. Garnons Williams, Tymawr, Brecon Mr. Geo. Winterson, Supt. of Police, Oak House, Crickhowell

Stephen W. Williams, Esq., J.P., F.S.A., Penrally, $R$ hayader

G. Hyatt Williams, Esq., Town Clerk of Brecon

John Williams Vaughan, Esq., J.P., Velinnewydd

Thomas Wood, Esq., J.P., \&c., Gwernyfed Park, Three Cocks

J. Whitaker, Esq., J.P., F.Z.S., Rain worth Lodge Notts

J. Wiglesworth, Esq., M.D., Rainhill

Capt. C. Harcourt Wood, Builth.

T. J. M. Watkins, Esq., F.S.A., "Portcullis," H.M. College of Arms (2 Copies)

Miss Williams, Penpont, Brecon.

C. H. deWinton, Esq., J.P., Buckingham House, Brecon.

Jonah Watkins, Essq., The Bank, Ilandovery.

Mrs Watkins, Tyruched, Glasbury-on-Wye

C. W. Woosnam, Ess., Cefnllysgwynne, Builth Mrs. Williams, Scethrog, Llansantffread, Brecon

Rev. M. Powell-Williams, Rector of Llansantffread

Mr. W. T. Wilkinson, 7, Maendu Street, Brecon

J. J. Baldwin Young, Esq., M.A., Richmond Park, Sheffield 



II SMITHSONIAN INSTITUTION LIBRARIES

39088 002556 5 nhbird QL690.G7P55

The birds of Breconshire / 